\title{
Multifamily Heat Pump Water Heater Evaluation
}

M. Hoeschele and E.Weitzel

Alliance for Residential Building Innovation (ARBI) 


\section{NOTICE}

This report was prepared as an account of work sponsored by an agency of the United States government. Neither the United States government nor any agency thereof, nor any of their employees, subcontractors, or affiliated partners makes any warranty, express or implied, or assumes any legal liability or responsibility for the accuracy, completeness, or usefulness of any information, apparatus, product, or process disclosed, or represents that its use would not infringe privately owned rights. Reference herein to any specific commercial product, process, or service by trade name, trademark, manufacturer, or otherwise does not necessarily constitute or imply its endorsement, recommendation, or favoring by the United States government or any agency thereof. The views and opinions of authors expressed herein do not necessarily state or reflect those of the United States government or any agency thereof.

This report is available at no cost from the National Renewable Energy Laboratory (NREL) at www.nrel.gov/publications.

Available electronically at SciTech Connect http:/www.osti.gov/scitech

Available for a processing fee to U.S. Department of Energy and its contractors, in paper, from:

U.S. Department of Energy

Office of Scientific and Technical Information

P.O. Box 62

Oak Ridge, TN 37831-0062

OSTI http://www.osti.gov

Phone: 865.576.8401

Fax: 865.576.5728

Email: reports@osti.gov

Available for sale to the public, in paper, from:

U.S. Department of Commerce

National Technical Information Service

5301 Shawnee Road

Alexandria, VA 22312

NTIS http://www.ntis.gov

Phone: 800.553 .6847 or 703.605 .6000

Fax: 703.605.6900

Email: orders@ntis.gov 


\title{
Multifamily Heat Pump Water Heater Evaluation
}

\author{
Prepared for: \\ The National Renewable Energy Laboratory \\ On behalf of the U.S. Department of Energy's Building America Program \\ Office of Energy Efficiency and Renewable Energy \\ 15013 Denver West Parkway \\ Golden, CO 80401 \\ NREL Contract No. DE-AC36-08GO28308 \\ Prepared by: \\ M. Hoeschele and E. Weitzel \\ Alliance for Residential Building Innovation \\ Davis Energy Group, Team Lead \\ 123 C Street \\ Davis, California 95616 \\ NREL Technical Monitor: Stacey Rothgeb \\ Prepared under Subcontract No. KNDJ-0-40340-00
}

March 2017 
The work presented in this report does not represent performance of any product relative to regulated minimum efficiency requirements.

The laboratory and/or field sites used for this work are not certified rating test facilities. The conditions and methods under which products were characterized for this work differ from standard rating conditions, as described.

Because the methods and conditions differ, the reported results are not comparable to rated product performance and should only be used to estimate performance under the measured conditions. 


\section{Contents}

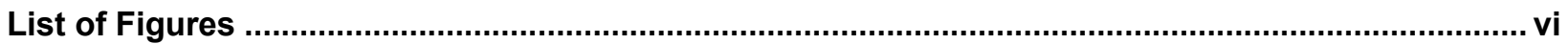

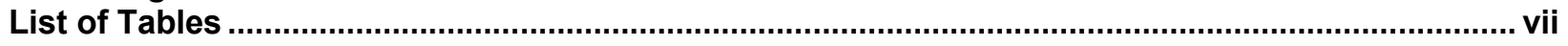

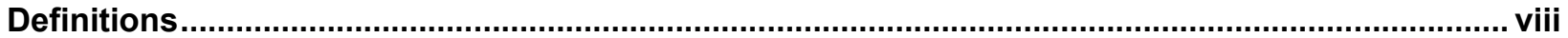

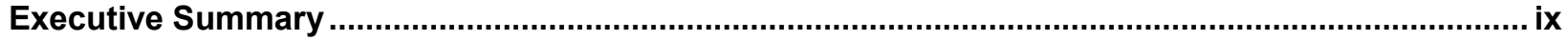

1 Introduction

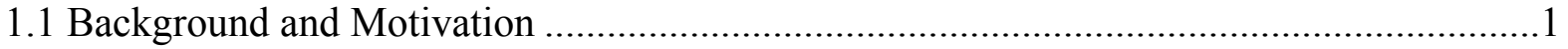

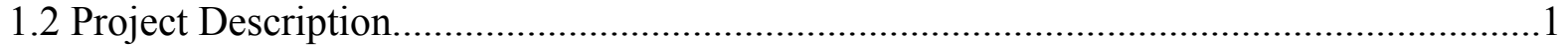

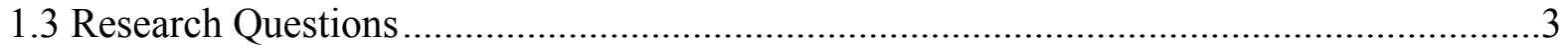

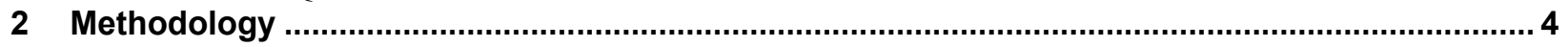

2.1 West Village Heat Pump Water Heater Specification and System Design .......................4

2.2 Heat Pump Water Heater Monitoring Approach ........................................................5

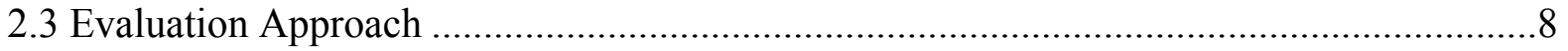

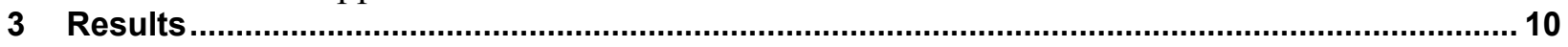

3.1 System Commissioning and Heat Pump Water Heater Operational Issues.....................10

3.2 Full-Load Monitoring Data Performance Trends .....................................................11

3.3 Developing a HPWH Performance Map............................................................... 14

3.4 Heat Pump Water Heater Performance Characteristics .............................................15

3.5 TRNSYS Model Validation Efforts..........................................................................20

3.6 Projected Performance in Different Climates ........................................................22

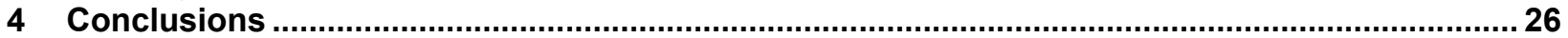

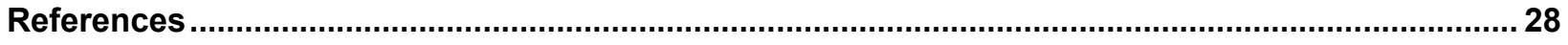

Appendix 


\section{List of Figures}

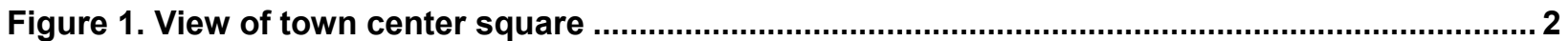

Figure 2. View of student apartments and leasing/recreation center.................................................. 3

Figure 3. Water-heating system configuration and monitoring sensor location ............................... 5

Figure 4. Monitored HPWH outdoor unit ..................................................................................... 6

Figure 5. Electric resistance storage tanks with capacities of $120 \mathrm{gal}$ with piping and monitoring sensors

Figure 6. Assumed multifamily hot water use profile ................................................................... 9

Figure 7. Full-load heating capacity as a function of outdoor dry-bulb temperature ....................... 12

Figure 8. Full-load HPWH demand as a function of outdoor dry-bulb and wet-bulb temperature ... 13

Figure 9. Full-load HPWH demand as a function of inlet water temperature......................................13

Figure 10. Full-load HPWH COP as a function of outdoor dry-bulb temperature ............................. 14

Figure 11. Daily hot water loads, HPWH energy delivered, and energy consumption ...................... 16

Figure 12. Comparison of daily water-heating energy use to thermal output ................................. 17

Figure 13. Monthly system performance summary ..................................................................... 17

Figure 14. Seasonal characterization of heat pump operation during typical weeks........................19

Figure 15. Average daily filtered cold water inlet temperature ..................................................... 20

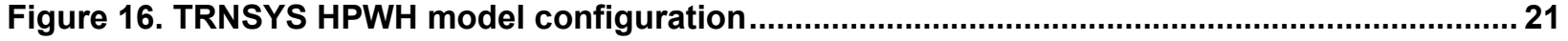

Figure 17. Projected annual operating cost comparison in selected climates ............................... 24

Figure 18. HPWH breakeven costs as a function of COP and utility rates .........................................2 25

Figure 19. Standby power dependence with air temperature........................................................ 29

Figure 20. Validation of model performance under typical winter conditions ................................... 30

Figure 21. Validation of model performance under typical fall conditions ........................................ 31

Unless otherwise noted, all figures were created by the ARBI team. 


\section{List of Tables}

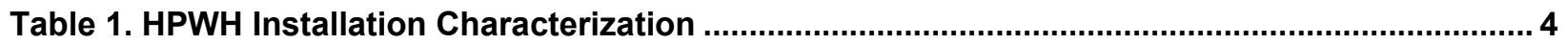

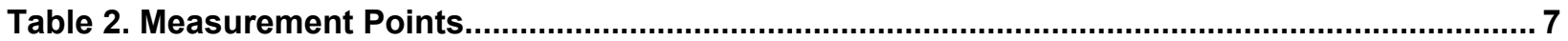

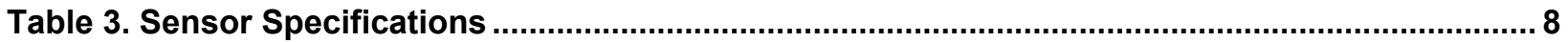

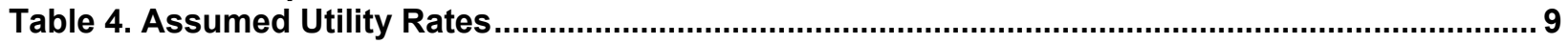

Table 5. Coefficients for the Biquadratic Functions Relating Capacity to Power .............................. 15

Table 6. Model Validation Results during Typical Winter and Fall 7-Day Period .............................22

Table 7. HPWH, Electric, and Gas Water Heater Performance Comparison in Selected Climates... 23

Unless otherwise noted, all tables were created by the ARBI team. 


\section{Definitions}

$\begin{array}{ll}\text { ARBI } & \text { Alliance for Residential Building Innovation } \\ \text { COP } & \text { coefficient of performance } \\ \text { DHW } & \text { domestic hot water } \\ \text { HPWH } & \text { heat pump water heater } \\ \text { kBtu } & \text { Thousand British thermal units } \\ \text { kW } & \text { kilowatt, electrical demand } \\ \text { kWh } & \text { kilowatt-hour } \\ \text { RH } & \text { relative humidity } \\ \text { TRNSYS } & \text { TRaNsient System Simulation program }\end{array}$




\section{Executive Summary}

More than $40 \%$ of U.S. households provide domestic hot water using electric resistance storage water heaters (D\&R International, Ltd. 2010). A significant opportunity exists to improve waterheating energy efficiency in these households through the use of heat pump water heaters (HPWHs), which offer potential energy savings of 50\% or more. Sales of HPWHs serving individual homes or apartments have increased in recent years through a combination of aggressive manufacturer marketing and utility incentives. Evaluations of HPWHs serving a central water-heating system have not been widely completed, making this effort valuable in documenting their performance and identifying issues. In this project, the Alliance for Residential Building Innovation team monitored the performance of a central HPWH installed on student apartments at the University of California, Davis, West Village zero net energy community. The HPWH system, one of 32 currently installed at West Village, was monitored in detail during a 16-month period. Monitoring results were used to validate a Transient System Simulation (TRNSYS) model. The validated model was then applied to six U.S. climates to evaluate performance using local weather and utility rates.

The nominal 127,000 Btu/h E-Tech air-source HPWH was installed with two 120-gal storage tanks in series (with electric elements of $54 \mathrm{~kW}$ for supplemental heating) to provide hot water to a 12-unit apartment building serving 32 occupants. The system was monitored from October 2011 through February 2013. When the monitoring was initiated in 2011, it was immediately determined that the HPWH was not operating properly - primarily because of a lack of contractor familiarity with the technology. The initial problems were corrected, and the unit operated well until July 2012, when the evaporator fan motor failed and required replacement. Steady-state operating coefficients of performance (COPs) matched well with manufacturer values - although both heating capacities and power demand were $10 \%-20 \%$ lower than nominal values, primarily due to higher HPWH inlet water temperatures and lower system flow rates through the HPWH heat exchanger. Although steady-state operating data demonstrated COPs in the range from 3.0-4.0, monitoring during the 16 months indicated that operating cycles were frequently short, resulting in lower average efficiencies due to performance degradation during system start-up. Cycling degradation and fairly high standby parasitic energy consumption resulted in degrading the 3.0-4.0 COP steady-state readings to an annual average COP of 2.12. The performance degradation impact was most pronounced during the summer months when lower hot water loads, the increased effect of standby parasitic energy consumption, and the shorter compressor run cycle resulted in monthly average COPs ranging from 1.7-1.9.

Two weeks of field-monitored data at 15-minute intervals were used as inputs to validate a TRNSYS model of the as-built HPWH installation. The model was then extended to six U.S. climates-Phoenix, Houston, Sacramento, Seattle, Denver, and Chicago — to project performance and estimate operating costs relative to conventional gas and electric storage base case scenarios. Annual energy savings relative to an electric base-case scenario ranged from $49 \%-59 \%$, or $\$ 1,920-\$ 3,475$, using local utility rates (resulting in simple paybacks of approximately 6-10 years). Savings relative to a gas water-heating base case were found to be more challenging, with none of the six locations projected to achieve a 10-year simple payback given the current low cost of natural gas in most regions of the United States. 
High-level project conclusions suggest that although savings of $50 \%$ or more relative to electric resistance water-heating systems are easily achievable, greater savings could be realized by optimizing system performance. Increasing the average compressor duty cycle through modified controls, use of variable-speed or two-stage compressors, and/or increased storage volumes would likely benefit the heat pump performance by increasing steady-state operation. Greater attention to reducing standby parasitic energy would also contribute to improving seasonal performance, especially in milder climates where HPWHs should demonstrate the maximum savings potential relative to conventional electric resistance water heating. Finally, the technology is still not mature, and therefore it is constrained by a small market share; this translates to high equipment costs, limited contractor familiarity, and difficulties in providing a robust service infrastructure.

The primary intended audiences for this study are water-heating researchers, utilities, and manufacturers of the larger central HPWHs. Early efforts to document the performance of these systems and identify improvement options can lead to better product offerings, improved design methods, and more thorough operation and maintenance procedures. 


\section{Introduction}

\subsection{Background and Motivation}

More than $40 \%$ of U.S. households heat domestic hot water (DHW) using electric resistance storage water heaters (D\&R International, Ltd. 2010). A significant opportunity exists to improve water-heating energy efficiency in these households through the use of heat pump water heaters (HPWHs), which offer expected energy savings of 50\% or more. Sales of HPWHs serving individual homes or apartments have increased in recent years through a combination of aggressive manufacturer marketing and utility incentives. Although significant attention has focused on the monitoring and evaluation of single-family HPWHs (Amaranth and Bush 2012; Pacific Gas and Electric Company 2010), very little data are available on the performance of larger, central HPWH systems (Gray 2010). Part of this is because not been many central HPWH installations have been monitored to date, and the product options are much more limited than the HPWHs scaled to single families.

In this project, the Alliance for Residential Building Innovation (ARBI) team monitored the performance of a central HPWH installed on a 14,200- $\mathrm{ft}^{2}$ student apartment building (12 apartments) at the University of California, Davis, West Village zero net energy community. The nominal 10.5-t HPWH serving the building was coupled to two 120-gal electric hot water tanks (in series), which provided both storage capacity and $54 \mathrm{~kW}$ of supplemental resistance heat. With increasing interest in community-scale zero net energy projects, it is important to develop case studies that document cost-effective solutions and lessons learned in a range of climates and applications. This will help identify strategies that work reliably and those that may need more development and support through the implementation process.

Becvause previous field-testing of single-family HPWHs showed lower than rated field performance due to a variety of factors - including hot water load intensity, unit location, and other issues - monitoring of the central HPWH installation will be beneficial in documenting the field performance of a commercial-scale system under varying climate and use conditions. The student-occupied apartments also represent a hot water usage pattern that is likely more diversified than those of a typical single-family application.

This project addresses a key Building America Water Heating Standing Technical Committee gap and barrier: evaluating HPWH field performance to characterize how climate, behavior, hot water loads, and system configuration affect performance and customer satisfaction.

\subsection{Project Description}

The University of California, Davis, West Village project, located approximately 15 miles west of Sacramento in California's hot-dry Central Valley climate, was the largest zero net energy mixed-use community under construction in the United States as of 2010 (Kerlin 2013). Ultimately the 130-acre project will provide housing for almost 2,000 students, 343 single-family homes for faculty and staff, and include a town center with both office space and retail. To date, a mixed-use town center and much of the student housing has been completed, and single-family home construction is slated to begin in late 2013. The project's approach to zero net energy design focused on integrating cost-effective energy-efficiency measures with renewable generation in the form of photovoltaics and a biogas system utilizing campus agricultural waste. In addition to the HPWHs, installed energy-efficiency measures include: 
- High-efficiency air-source heat pumps for space heating and cooling

- Increased wall and attic insulation and attic radiant barriers

- Home Energy Rating System Index inspections on insulation quality, duct leakage, and envelope leakage

- High-performance windows,

- $100 \%$ high-efficacy lighting

- EnergyStar ${ }^{\circledR}$ appliances.

Although space-conditioning heat pumps and central HPWHs are generally not common in the Davis, California, area due to the widespread availability of comparatively inexpensive natural gas, they were implemented in the student apartment design as a key component of an all-electric energy-efficiency strategy.

For the student apartments, 37\% source energy savings were projected throughout the B10 Benchmark in hot-dry climates (Dakin et al. 2012). These measures, and specifically the package of measures, have the potential to lead to market-ready solutions that cost-effectively provide comfort in multifamily buildings with efficient, safe, and durable operation.

Figure 1 shows the town center square with retail/office space on the ground level and apartments above, and Figure 2 provides a broader view of the project with student apartment buildings and the leasing/student recreation center to the left. Most of the apartment buildings contain 12 apartments with a mix of 2-, 3-, and 4-bedroom units.

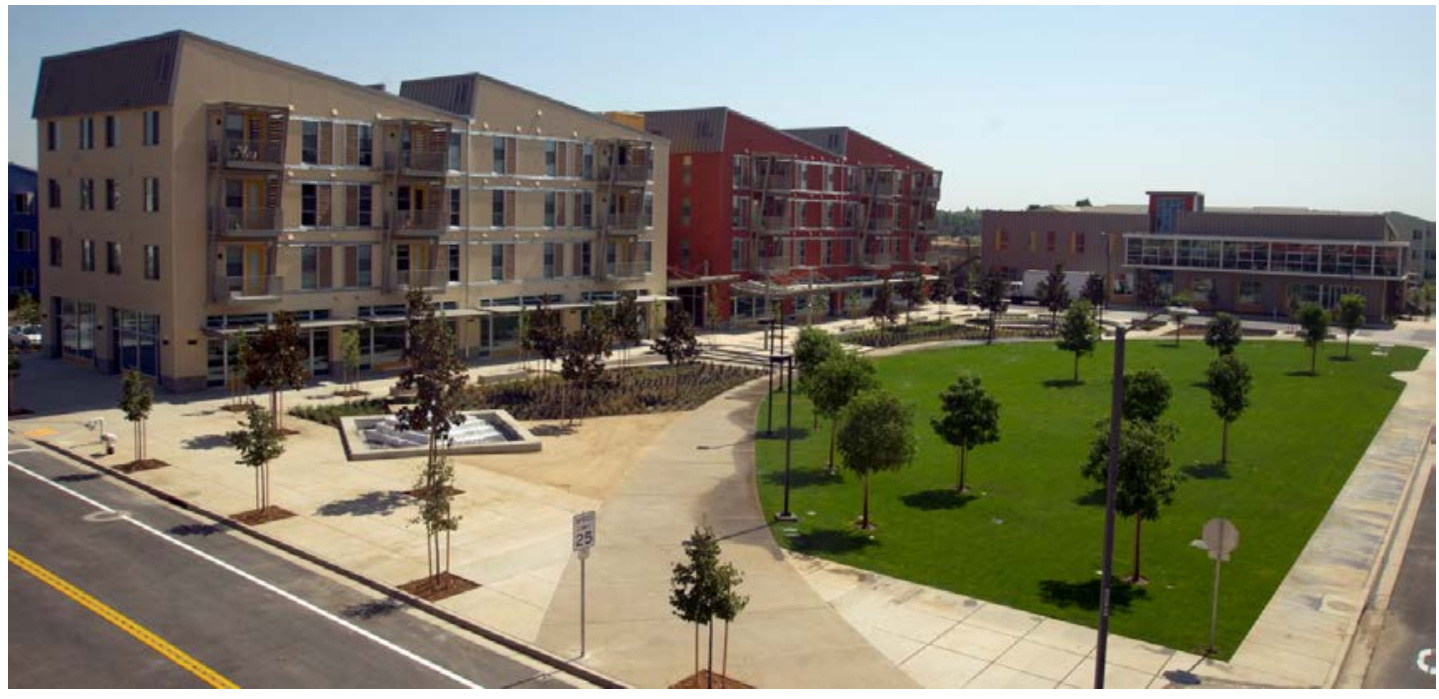

Figure 1. View of town center square 


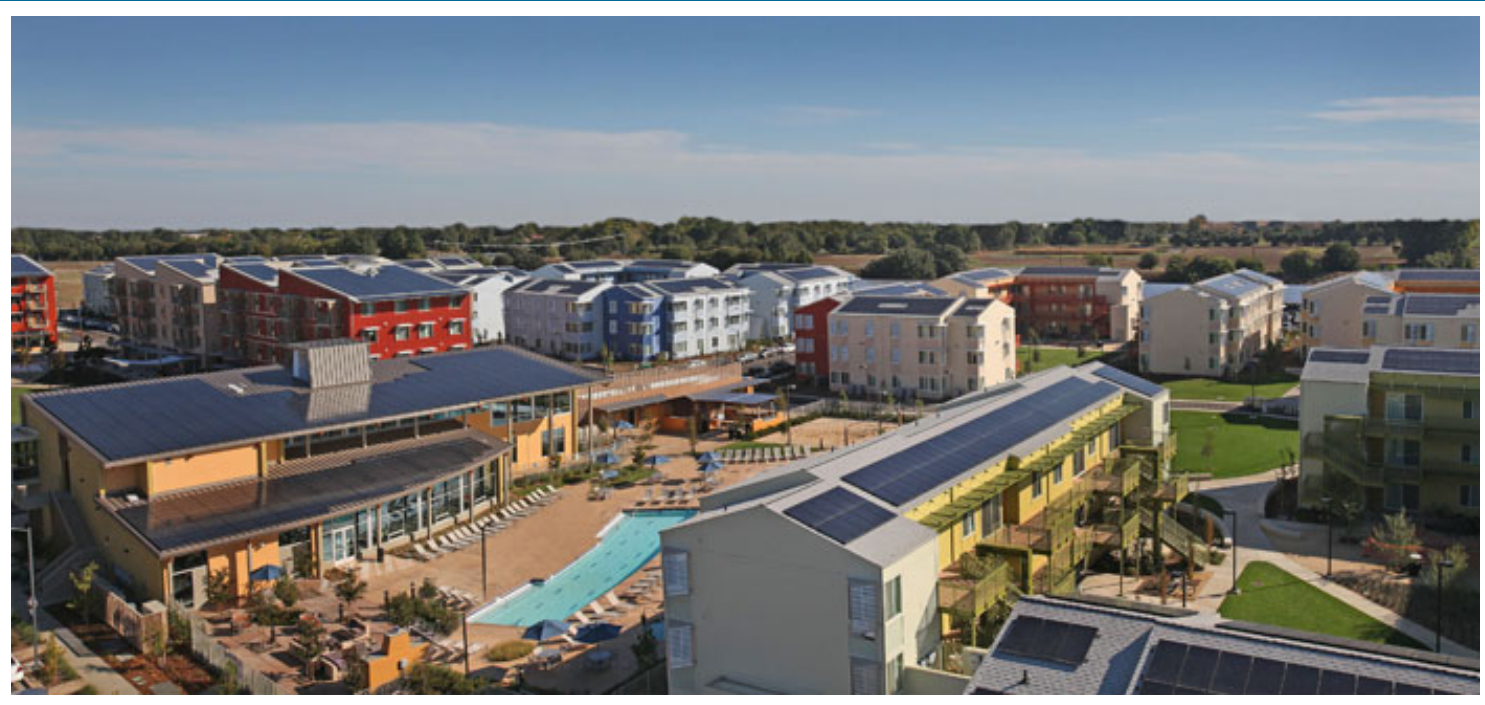

Figure 2. View of student apartments and leasing/recreation center

\subsection{Research Questions}

The primary objective of this project was to evaluate the performance and efficiency of the central HPWHs as a strategy to provide efficient electric water heating for multifamily applications where natural gas is unavailable or where favorable electric rates provide a competitive environment relative to gas water heating.

Research questions include the following:

1. What is the measured performance and reliability of the central HPWHs, and how does it compare to expectations from modeling and manufacturer claims?

2. How viable is the central HPWH system to other conventional options under varying retail rate scenarios?

3. Under what load and ambient conditions does the HPWH fail to meet the load, and how frequently does this occur?

4. How does the ratio of the HPWH sizing to peak load compare to typical single-family applications, and what are the performance implications?

Proposed monitoring and modeling efforts will be used to provide answers to these questions and determine how effective the approach is in contributing to meeting Building America performance goals. Overall incremental costs and energy use of the HPWH will be used to evaluate the costs and benefits of a centralized HPWH system for multifamily residences for various types of conventional systems in different climates. 


\section{Methodology}

2.1 West Village Heat Pump Water Heater Specification and System Design A 2012 ARBI study (Dakin et al. 2012) documented the West Village design processes surrounding the development of the package of energy-efficiency measures. The 2012 report presents the 2009 evaluation of heating, ventilating, and air-conditioning and water-heating options completed in conjunction with the West Village Community Partnership, LLC (the West Village project developers). The developers selected individual apartment gas storage water heaters as the reference base case system type for comparison to higher efficiency alternatives. Incremental costs for the central HPWH design were initially estimated at $\$ 12,800$ per building (or slightly less than $\$ 1,100$ per apartment). Once bids were received, the incremental cost was found to be only $\$ 500$ per apartment. Additional cost savings were realized by eliminating gas lines and venting and freeing up some additional interior floor space required for the individual water heaters. Including these factors, the developer determined that the central HPWH would incur zero incremental costs. With that information and a desire to pursue an all-electric solution for the student apartments, West Village Community Partners chose to install central HPWHs.

The mechanical engineer of record for the project worked with A.O. Smith to select an appropriate piece of equipment. The engineer selected an A.O. Smith (E-Tech $\left.{ }^{1}\right)$ WH115-HTC HPWH to satisfy each building's DHW loads. Specifications of the unit and the HPWH installation can be found in Table 1, and a system schematic is shown in Figure 3. The manufacturer suggested that the system be configured so that the HPWH maintains water temperatures of $140^{\circ} \mathrm{F}$ in the primary storage tank. Resistance elements in the two electric storage tanks were scheduled to maintain minimum tank temperatures of $120^{\circ} \mathrm{F}$, allowing the HPWH to meet the bulk of the water-heating load. A tempering valve downstream of the second storage tank was set to limit the supply water temperature to the recirculation loop at $120^{\circ} \mathrm{F}$. A hot water recirculation loop pump serving the building is controlled by both a return water temperature sensor and a timer that shuts it off during part of the night.

Table 1. HPWH Installation Characterization

\begin{tabular}{l|l}
\hline \multicolumn{1}{c|}{ Parameter } & \multicolumn{1}{c}{ Description } \\
\hline Building Size $\left(\mathrm{ft}^{2}\right)$ & 14,200 \\
\hline No. of Apartments & $\begin{array}{l}\text { Six four-bedroom units, } \\
\text { six two-bedroom units }\end{array}$ \\
\hline No. of Stories & Three \\
\hline HPWH Make and Model & $\mathrm{AO} \mathrm{Smith} \mathrm{(E-Tech)} \mathrm{WH115-HTC}$ \\
\hline \multirow{2}{*}{ Nominal Capacity (Btu/hr) } & $\begin{array}{l}127,000\left(\text { at } 85^{\circ} \mathrm{F} \text { dry bulb, 50\% }\right. \\
\mathrm{RH}, 100^{\circ} \mathrm{F} \text { inlet water } \\
\text { temperature, 25 gpm) }\end{array}$ \\
\hline Storage Configuration & $\begin{array}{l}\text { Two 120-gal electric tanks in } \\
\text { series (54 kW in each tank) }\end{array}$ \\
\hline \multirow{2}{*}{ Distribution System } & $\begin{array}{l}\text { Time/temperature recirculation } \\
\text { control; } 1-1 / 4 " \text { insulated hot water } \\
\text { supply and return lines }\end{array}$ \\
\hline
\end{tabular}

\footnotetext{
${ }^{1}$ A.O. Smith purchased E-Tech in 2009.
} 


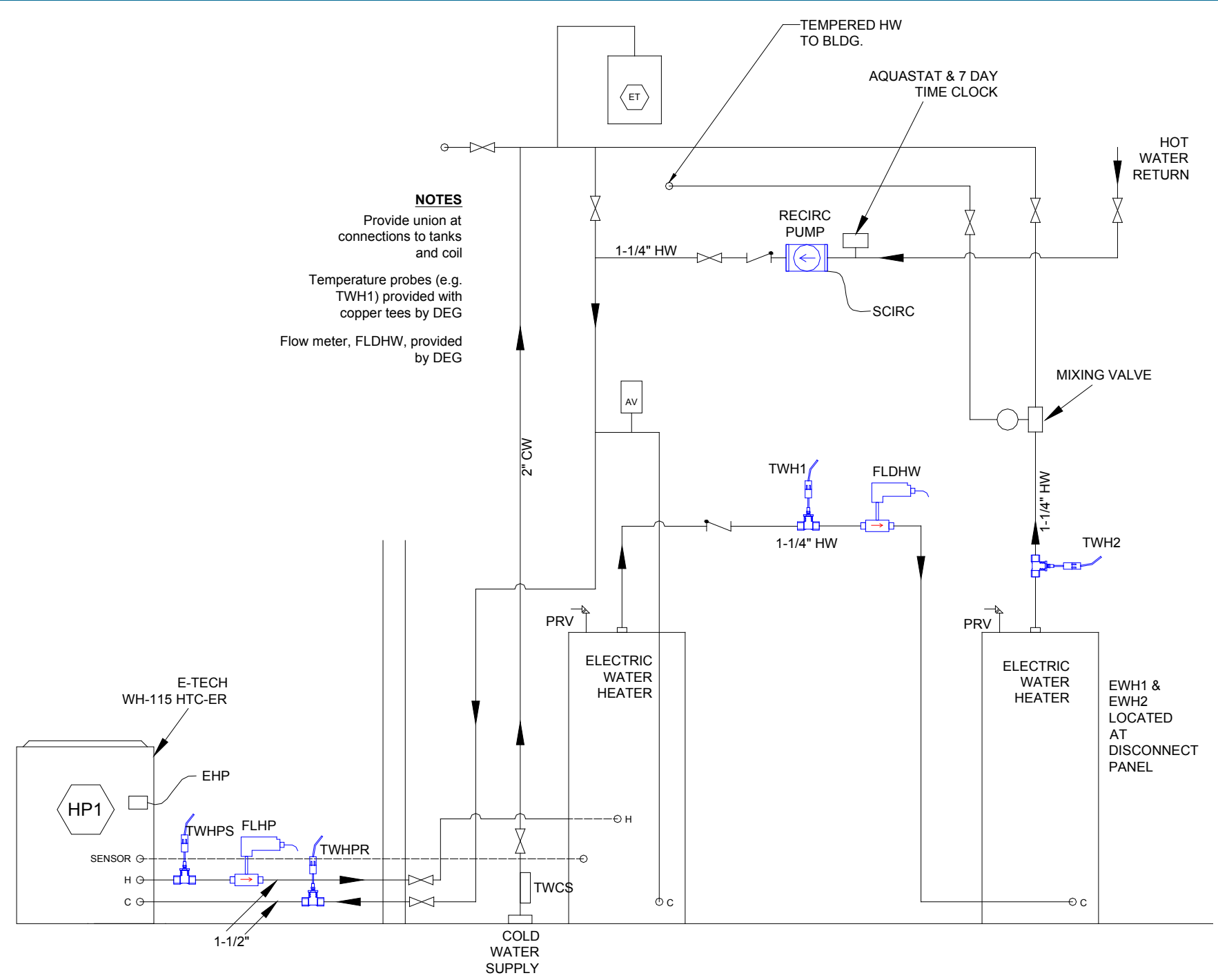

Figure 3. Water-heating system configuration and monitoring sensor location

\subsection{Heat Pump Water Heater Monitoring Approach}

The monitoring strategy focused on characterizing HPWH performance (capacity, power, and efficiency) as a function of hot water load, varying return water temperatures, and outdoor temperature effects. A minimum 12-month monitoring period was planned to adequately capture seasonal performance effects associated with climate, cold water inlet temperature variations, and hot water load variations during the course of the academic year. Water-heating energy flows were calculated at 15 -second intervals using water-side measurements (flow multiplied by temperature difference), as shown in Eq. 1. Energy flows were totaled and reported at 15-minute intervals. HPWH efficiency (Eq. 2) was calculated on a 15-minute basis by dividing the HPWH energy delivered by the energy consumed. The HPWH schematic shown in Figure 3 depicts the location of the installed monitoring equipment, and Figure 4 and Figure 5 show the outdoor HPWH unit and the configuration of the indoor mechanical room with flow meters and temperature sensors installed, respectively. 


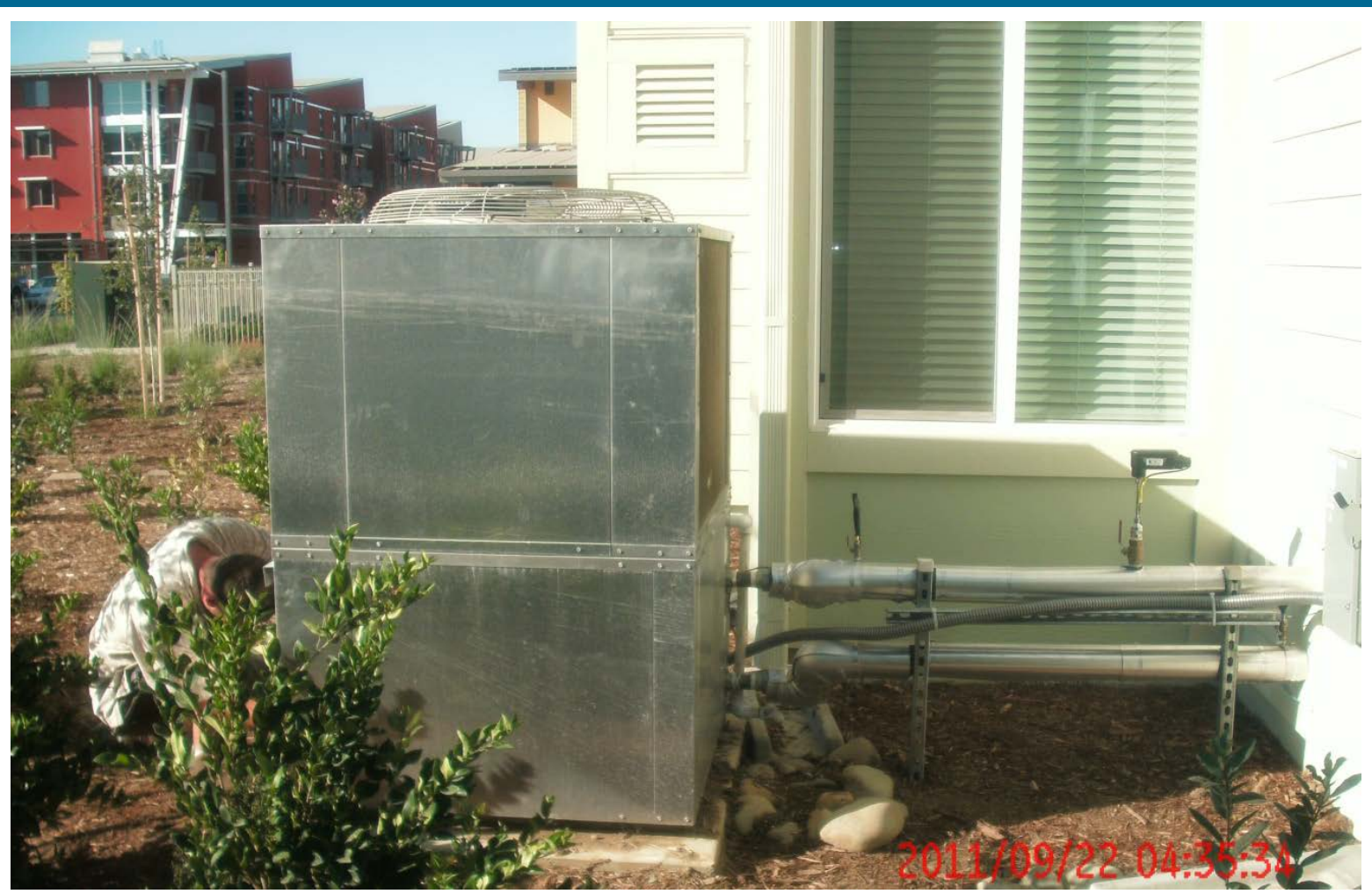

Figure 4. Monitored HPWH outdoor unit

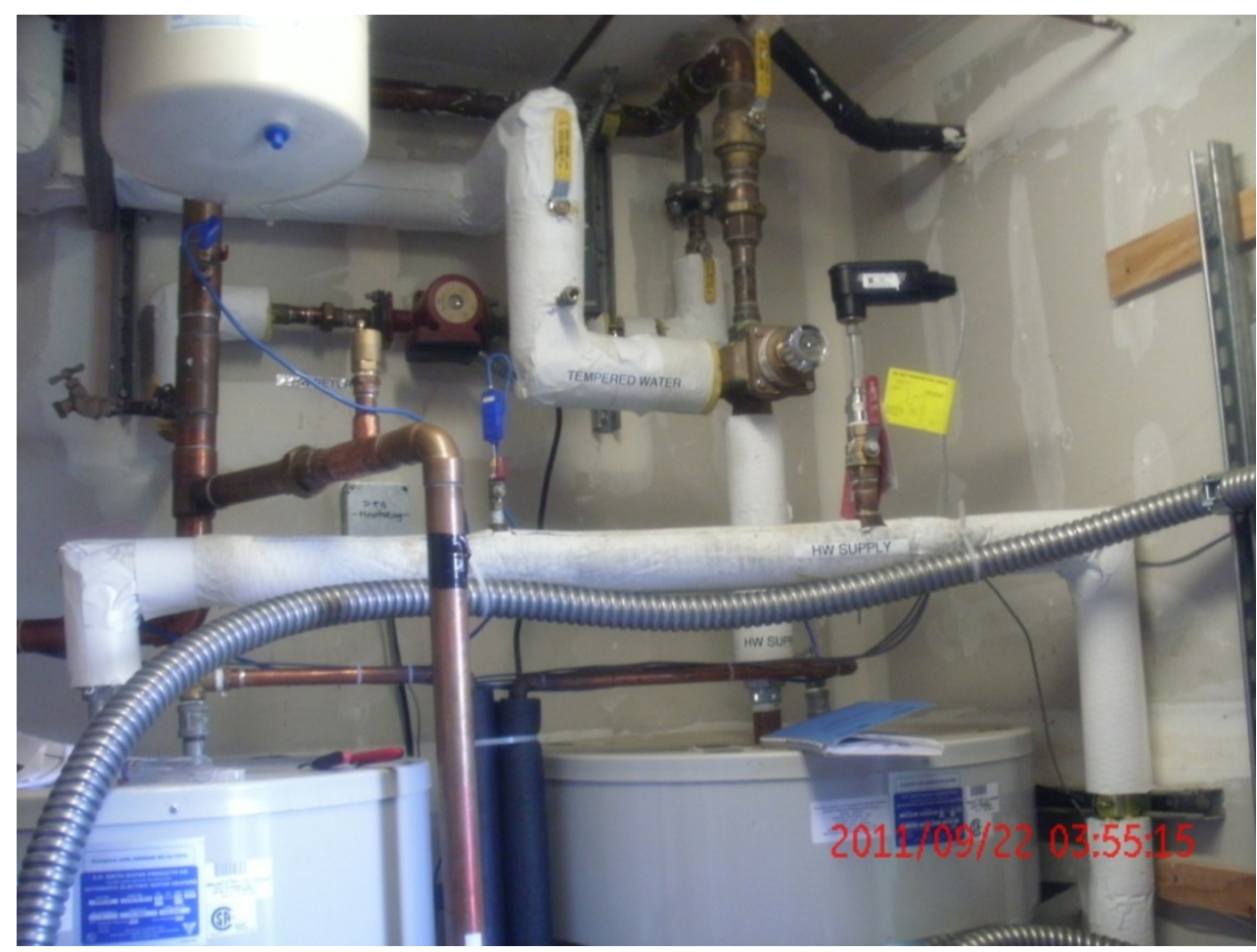

Figure 5. Electric resistance storage tanks with capacities of 120 gal with piping and monitoring sensors 


\section{$\mathrm{Q}(\mathrm{kBtu})=8.33 *$ FLOW $*(\mathrm{THOT}-\mathrm{TCOLD}) * 0.001$}

Where:

- FLOW = 15-second flow to the HPWH (gallons/15 seconds)

- $\mathrm{THOT}=$ temperature leaving the HPWH condenser $\left({ }^{\circ} \mathrm{F}\right)$

- $\mathrm{TCOLD}=$ temperature entering the HPWH condenser $\left({ }^{\circ} \mathrm{F}\right)$.

Efficiency $(\mathrm{COP})=(0.001 * \mathrm{Q}(\mathrm{kBtu})) /(\mathrm{HPWH} \mathrm{kWh} * 3.413)$

Where:

- $\mathrm{Q}(\mathrm{kBtu})=$ summed 15-minute HPWH heat delivery (Btu/15 minutes)

- HPWH kWh = HPWH energy consumed during 15 minutes.

Table 2 lists the measurement points monitored on a continuous basis, and Table 3 lists the sensors and their performance specifications. A programmable Thermo Fisher Scientific dataTaker data logger and cellular modem were used for continuously collecting, storing, and transferring data to the ARBI host computer.

Table 2. Measurement Points

\begin{tabular}{|c|c|c|c|}
\hline Abbreviation & Description & Location & Sensor Type \\
\hline TAO & Outdoor air temperature & \multirow{2}{*}{ Shield location near HPWH } & RTD, 4-20 milliAmp \\
\hline $\mathrm{RHO}$ & Outdoor RH & & RTD, 4-20 milliAmp \\
\hline TWRECIRC & $\begin{array}{l}\text { Water temperature-- } \\
\text { recirculation }\end{array}$ & Mechanical room-DHW & $\begin{array}{l}\text { Immersion } \\
\text { thermocouple }\end{array}$ \\
\hline TWHPS & $\begin{array}{l}\text { Water temperature heat pump } \\
\text { supply }\end{array}$ & Mechanical room—DHW & $\begin{array}{l}\text { Immersion } \\
\text { thermocouple }\end{array}$ \\
\hline TWHPR & $\begin{array}{l}\text { Water temperature heat pump } \\
\text { return }\end{array}$ & Mechanical room—DHW & $\begin{array}{l}\text { Immersion } \\
\text { thermocouple }\end{array}$ \\
\hline TWH1 & $\begin{array}{l}\text { Outlet water temperature-- } \\
\text { Electric Water Heater } \# 1\end{array}$ & Mechanical room—DHW & $\begin{array}{l}\text { Immersion } \\
\text { thermocouple }\end{array}$ \\
\hline TWH2 & $\begin{array}{l}\text { Supply water temperature- } \\
\text { Electric Water Heater \#2 }\end{array}$ & Mechanical room—DHW & $\begin{array}{l}\text { Immersion } \\
\text { thermocouple }\end{array}$ \\
\hline TWCS & Cold water inlet temperature & Mechanical room—DHW & $\begin{array}{l}\text { Pipe surface } \\
\text { thermocouple }\end{array}$ \\
\hline FLHP & Flow to HPWH & Outdoors, near heat pump & Flow meter \\
\hline FLDHW & Flow-DHW & Mechanical room-DHW & Flow meter \\
\hline EHP & Heat pump energy & Mechanical room-service panel & Power meter \\
\hline EWH1 & Electric Heater \#1 Energy & Mechanical room-service panel & Power meter \\
\hline EWH2 & Electric Heater \#2 energy & Mechanical room-service panel & Power meter \\
\hline SCIRC & Recirculation pump status & Mechanical room-DHW & Status \\
\hline FLRecirc & Recirculation return flow & Mechanical room—DHW & Flow meter \\
\hline
\end{tabular}


Table 3. Sensor Specifications

\begin{tabular}{l|l|l|l|l|l}
\hline \multicolumn{1}{c|}{ Type } & \multicolumn{1}{c|}{ Application } & $\begin{array}{l}\text { Manufacturer/ } \\
\text { Model }\end{array}$ & \multicolumn{1}{c}{ Signal } & \multicolumn{1}{c}{ Span } & Accuracy \\
\hline RTD & $\begin{array}{l}\text { Outdoor temperature } \\
\text { and RH }\end{array}$ & $\begin{array}{l}\text { Vaisala } \\
\text { HMY60 }\end{array}$ & $4-20 \mathrm{~mA}$ & $\begin{array}{l}14^{\circ} \mathrm{F}- \\
140^{\circ} \mathrm{F} ; \\
0 \%-100 \%\end{array}$ & $\begin{array}{l} \pm 0.5 \%{ }^{\circ} \mathrm{F} \\
\pm 2 \% \mathrm{RH}\end{array}$ \\
\hline $\begin{array}{l}\text { Type T } \\
\text { Thermocouple }\end{array}$ & $\begin{array}{l}\text { Immersion water } \\
\text { temperatures }\end{array}$ & Omega Type T & $\begin{array}{l}\sim 11 \mathrm{mV} @ \\
500^{\circ} \mathrm{F}\end{array}$ & $\pm 0.4 \%$ \\
\hline Flow meter & Water flow & Onicon F-1100 & Pulse & $\begin{array}{l}1-130 \\
\text { gpm }\end{array}$ & $\pm 0.5 \% *$ \\
\hline Power monitor & $\begin{array}{l}\text { HPWH power and eletric } \\
\text { Storage }\end{array}$ & $\begin{array}{l}\text { Wattnode/ } \\
\text { WNB-3D-240- }\end{array}$ & Pulse & $\pm 0.5 \%$ \\
\hline 24VAC relay & Status & Hawkeye & Dry contact & $\mathrm{n} / \mathrm{a}$ & $\mathrm{n} / \mathrm{a}$ \\
\hline
\end{tabular}

$* 0.5 \%$ at the calibration flow rate $( \pm 1 \%-2 \%$ of reading throughout a flow range of $50: 1)$

\subsection{Evaluation Approach}

The planned approach for evaluating HPWH performance involved utilizing full-load data to develop a performance map describing system performance as a function of inlet water temperatures and outdoor air temperature. The as-built HPWH configuration at West Village could then be modeled using the TRNSYS v17 Type 941 heat pump model and the capacity and power performance maps. The Type 941 model is a single-stage air-to-water heat pump model that takes the user-supplied performance map (with fractional capacity and power multipliers based on entering water and air temperature) and applies the factors to user-input nominal performance values. The model interpolates these steady-state performance maps to determine the output capacity and power during each time step when the HPWH operates. A Type 534 storage water heater model was used for each of the 120-gal electric storage water heaters. The storage model utilized 10 vertically stratified nodes in the first tank and 8 nodes in the second tank, with greater resolution in the first tank needed to capture the connections to and from the HPWH.

Two weeks of field data, typical of fall and winter fully occupied schedules, were selected to be used in the model validation process. Monitored outdoor temperatures, inlet cold water temperatures, and hot water flows were used to drive the model. The goal of the validation effort was to match the weekly energy generated by the HPWH and weekly energy consumed by the system. It was difficult to match the model to the monitored data on a short timescale because the TRNSYS needed to be run on a 15 -second timescale to adequately represent system control characteristics. Because collected hot water usage data were logged at 15-minute intervals, the flow could be distributed uniformly only during the 6015 -second TRNSYS time steps, which introduced some level of inaccuracy. Validation efforts included adjusting the number of tank stratification nodes, mixing rates between nodes, tank port locations, pipe insulation characteristics, and aquastat and temperature sensor locations. All efforts were made to model the as-built system with minimal adjustments to known physical parameters.

The final step in the evaluation process was to exercise the validated model through various climates using a typical standard draw profile based on ASHRAE Service Water Heating profiles (ASHRAE 2011) for apartments. Figure 6 plots the assumed fraction of the hourly hot water load assumed in this study based on the ASHRAE profiles. A daily nominal hot water load of 11 
gal/person-day was assumed with a total building occupancy of 42 people. Typical meteorological year data for each climate was used to drive the model with outdoor ambient air temperature, humidity, pressure, and inlet water mains temperature. Hot water usage was adjusted for each climate (ranging from $-4 \%$ in Phoenix to $+7 \%$ in Chicago) to adjust for variable distribution loss impacts due to climate (Backman and Hoeschele 2013). During model validation, the monitored recirculation flow rate and temperatures were fed into the system as inputs. For the climate performance evaluation, the hot water end-use loads (i.e., delivered hot water at the fixtures) were increased by $30 \%$ to approximate the "typical" magnitude of the recirculation loop thermal energy impacts derived from a recent monitoring study (Zhang et al. 2012).

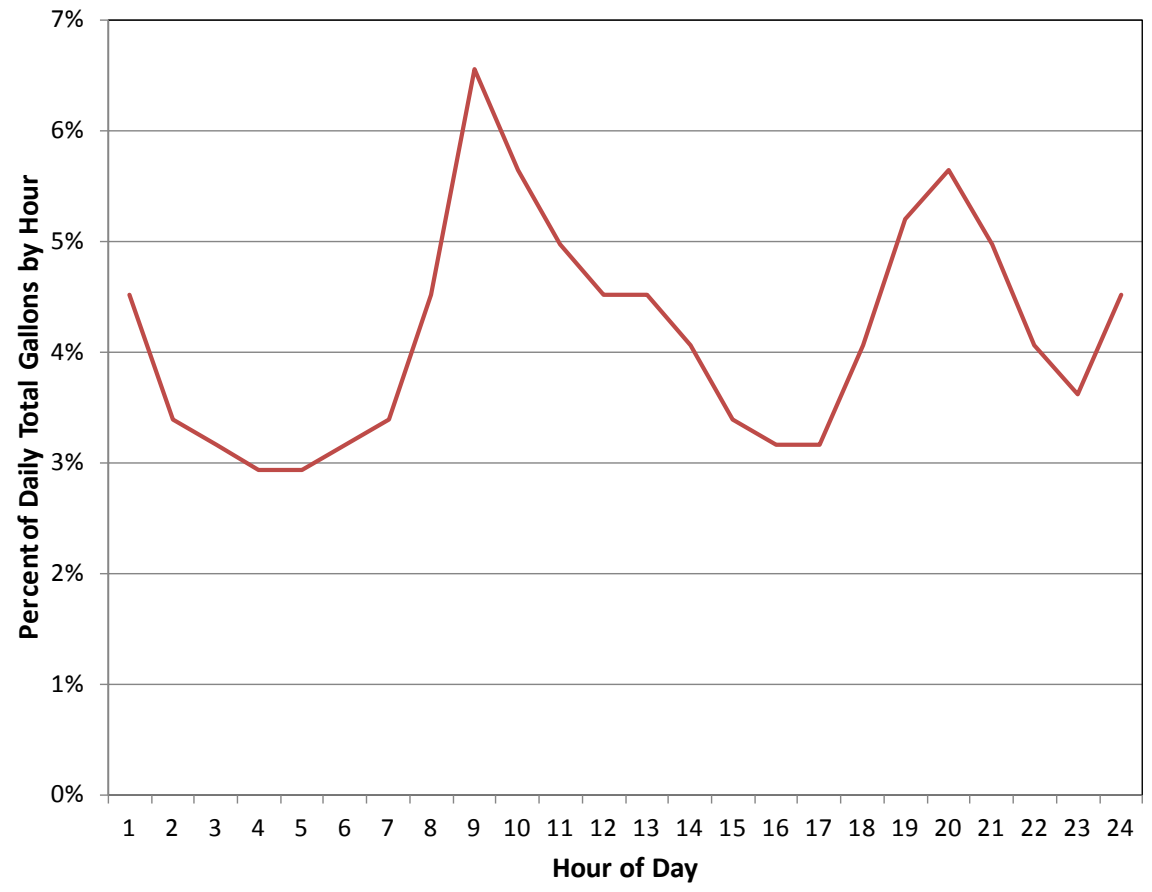

Figure 6. Assumed multifamily hot water use profile

Assumed utility rates for each location (shown in Table 4) were calculated based on statewide information provided by the U.S. Energy Information Administration (2014).

Table 4. Assumed Utility Rates

\begin{tabular}{l|c|c}
\hline \multicolumn{1}{c|}{ Location } & $\begin{array}{c}\text { Gas Rate } \\
\text { (\$/therm) }\end{array}$ & $\begin{array}{c}\text { Electric Rate } \\
\text { (\$/kWh) }\end{array}$ \\
\hline Phoenix & 1.485 & 0.1108 \\
\hline Houston & 0.993 & 0.1108 \\
\hline Seattle & 1.195 & 0.0828 \\
\hline Sacramento & 0.974 & 0.1478 \\
\hline Denver & 0.800 & 0.1127 \\
\hline Chicago & 0.869 & 0.1178 \\
\hline
\end{tabular}




\section{Results}

\subsection{System Commissioning and Heat Pump Water Heater Operational Issues}

The value of proper commissioning was made evident as part of the ARBI team's experience with the West Village HPWH. After the monitoring system was installed and commissioned in mid-September 2011 (shortly after the first apartments were occupied by the students), the ARBI team immediately observed that the HPWH was not operating properly. The evaporator fan and HPWH circulating pump were running continuously, giving the impression that the HPWH was operating, although in reality the entire water-heating load was being met by the backup electric storage water heaters. This was not intuitively obvious to the installing plumbers and the site maintenance team given their lack of familiarity with the technology and the shortcomings of the HPWH control interface. ${ }^{2}$ The fact that the compressor was not operating was not evident by simple visual observation, unless one observed the unit continuously for 30 minutes or more and could note that the unit did not shut off during that period of time.

ARBI notified West Village Community Partners field-service personnel and the installing plumber of the problems, and soon the equipment manufacturer was also brought in to assess the situation. An A.O. Smith representative inspected the installation in late September and determined that a remote immersion sensor for the heat pump had not been properly installed. A.O. Smith provided the temperature sensor that had initially been installed on the storage tank wall exterior. Subsequent monitoring results showed that the heat pump still did not operate. The A.O. Smith representative then indicated that the tank sensor needed to be relocated to a thermal well inside the storage tank. The system was then set up per manufacturer recommendations:

- $140^{\circ} \mathrm{F}$ heat pump upper limit set point $\left(5^{\circ} \mathrm{F}\right.$ dead band $)$

- $120^{\circ} \mathrm{F}$ resistance heat set point in each tank

- $120^{\circ} \mathrm{F}$ setting on the tempering valve that feeds the recirculation loop.

With this strategy, the HPWH became the primary heating source with limited electric resistance heating expected. The downside of the high HPWH set point is that higher condensing temperatures will lead to lower heat pump efficiencies. If the set points for both the heat pump and storage tank water heaters could be lowered without compromising hot water delivery temperatures, the heat pump would operate at higher efficiencies, provided compressor shortcycling did not adversely degrade performance.

After the October 2011 recommissioning exercise, the HPWH operated reliably and almost exclusively without the need for electric resistance backup heating through early December 2012. The one problem encountered during that time span was a failure of the evaporator fan motor bearings in early July 2012, which was promptly fixed. ${ }^{3}$ However, in early December 2012, the HPWH again went offline, resulting in all water-heating loads being satisfied by the

\footnotetext{
${ }^{2}$ The Crouzet micro logic controller is a custom programmable logic controller that can be configured for different applications.

${ }^{3}$ Although not common, bearings in the fan motors of conventional heating, ventilating, and air-conditioning equipment do occasionally fail. With a small sample size of units at the West Village project, it is not clear if this was a random occurrence or whether it will be an ongoing problem for the installed units.
} 
electric resistance water heaters. West Village Community Partners staff was notified, but for a variety of reasons ${ }^{4}$ the HPWH was not brought back online until the end of January 2013.

Identifying proper HPWH performance without the benefit of the ongoing monitoring was certainly a challenge for the field staff. The West Village experience highlights the need for increased contractor and service personnel training in proper installation and commissioning techniques, especially given that the HPWH technology is not commonly seen in this area. In addition, the vendor must provide a more intuitive user interface to facilitate system troubleshooting. Ideally the manufacturer should provide a simple set of measurements for basic system commissioning, including power (or amperage draw) and HPWH supply and return water temperature. The first phase of 16 student apartment HPWH systems (of which the monitored unit was one) were installed by the plumbing subcontractor. Due to the start-up problems associated with Phase I, the HPWH systems for the second phase of 16 apartments, which was completed in the summer of 2012, were commissioned by a heating, ventilating, and airconditioning contractor. ${ }^{5}$ Also, the 16 units for the Phase II construction were manufactured at an A.O. Smith facility and have had far fewer commissioning and service issues than the Phase I units.

\subsection{Full-Load Monitored Data Performance Trends}

Figure 7 through Figure 10 present full-load monitored data from November 2011 to November 2012. The manufacturer's data specification lists heating capacity and total heat pump power at four outdoor temperatures $\left(25^{\circ} \mathrm{F}, 45^{\circ} \mathrm{F}, 65^{\circ} \mathrm{F} \text {, and } 85^{\circ} \mathrm{F}\right)^{6}$ at assumed fixed inlet water temperatures of $100^{\circ} \mathrm{F}$ and a heat pump circulating flow rate of $25 \mathrm{gpm}$. For comparison, the full-load field-monitored data indicates an average inlet water temperatures of $125.4^{\circ} \mathrm{F}$ and a heat pump flow rate of $19.6 \mathrm{gpm}$. The lack of manufacturer's data at any other flow rate and the observed $20 \%$ flow discrepancy make any direct comparisons tenuous at best.

Figure 7 presents heating capacity data as function of outdoor air dry-bulb temperature. The monitored data show the expected trend of increasing heating capacity as outdoor temperatures rise. Outdoor temperature is used as the dependent variable (instead of outdoor wet-bulb temperature) to highlight the HPWH's system control strategy, which lowers the evaporator fan speed when the temperature is higher than $85^{\circ} \mathrm{F}$ to avoid excessive condensing pressures. The plotted manufacturer's data indicate an approximate 10\%-20\% higher HPWH capacity than observed, although the manufacturer's reported data assume return water temperatures of $100^{\circ} \mathrm{F}$ and a flow rate of $25 \mathrm{gpm}$, both of which were more favorable than what was observed in the field.

Figure 8 plots monitored HPWH electrical demand as a function of both outdoor air dry-bulb and wet-bulb temperature as well as the manufacturer's demand data. The manufacturer's data is approximately $10 \%-20 \%$ higher than the monitored data. The average heat pump inlet water temperature of the monitored full-load data was $25^{\circ} \mathrm{F}$ warmer than the performance values provided by the manufacturer. Another factor identified during data evaluation was the definition

\footnotetext{
${ }^{4}$ Including the upcoming holidays and campus winter break, other maintenance priorities, and the development of a plan to upgrade the capabilities and tools available for HPWH diagnostics and servicing.

${ }^{5}$ The initial 16 HPWH units installed during Phase I construction represent a manufacturing transition because A.O. Smith had just purchased E-Tech. This created some logistical issues with equipment delivery.

${ }^{6}$ With $50 \%$ RH.
} 
of 15-minute continuous operation as the steady state. With this definition, the steady state could be as short as 15 minutes or considerably longer. ${ }^{7}$ With HPWH start-up operation affecting performance for 5 minutes or more, variations in the 15-minute interval HPWH demand are to be expected. Figure 9 plots HPWH steady-state demand as a function of inlet water temperature to the unit. These data are better correlated and suggest an approximate $0.4-\mathrm{kW}$ increase in HPWH demand for every $10^{\circ} \mathrm{F}$ increase in inlet water temperature.

Figure 10 plots full-load monitored coefficients of performance (COP) as a function of outdoor temperature. Monitoring data are fairly well correlated, and the resulting full-load COPs match well with the manufacturer's data.

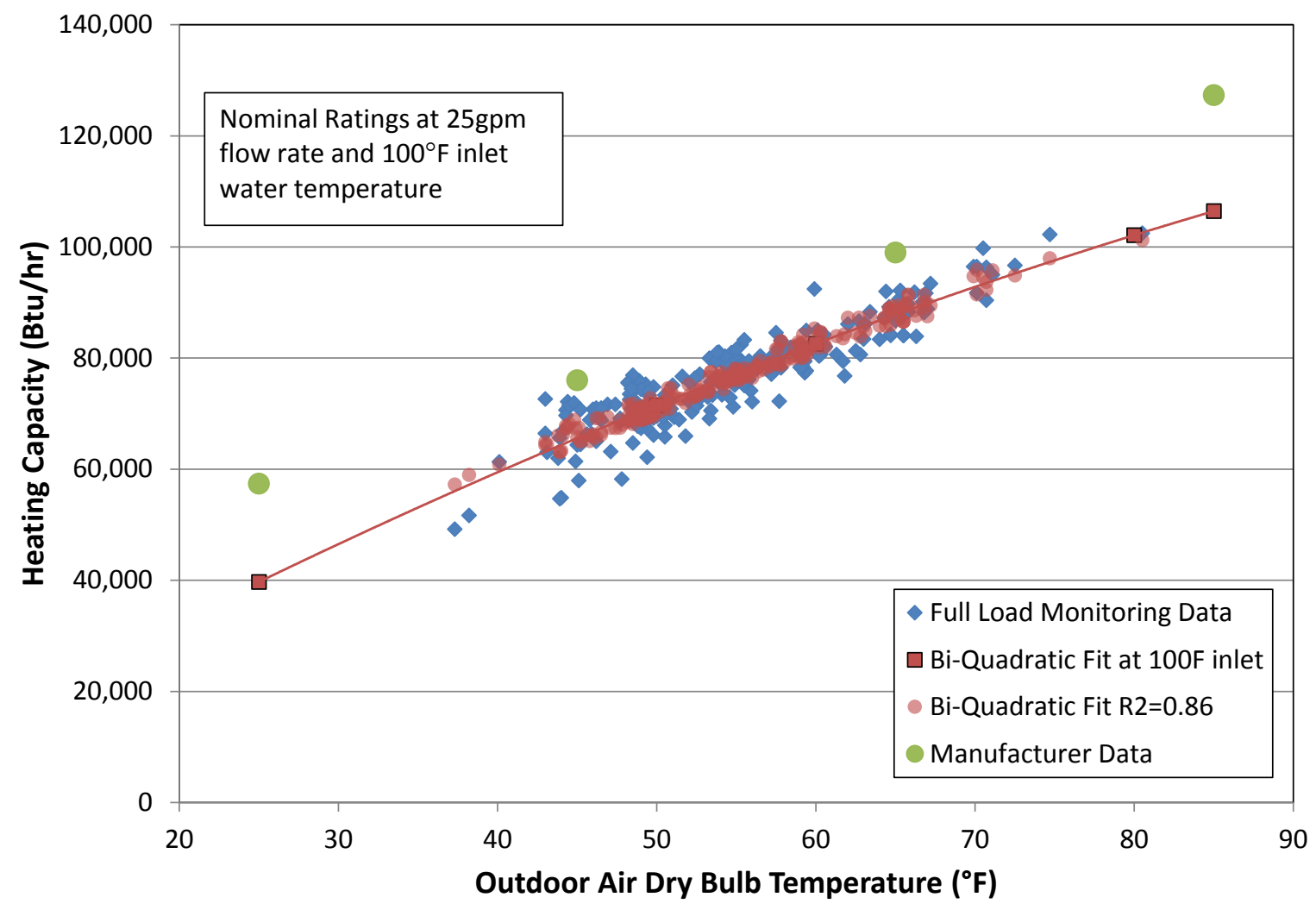

Figure 7. Full-load heating capacity as a function of outdoor dry-bulb temperature

\footnotetext{
${ }^{7}$ The 15-minute interval logging reported the fraction of the interval when the compressor was operating. It is therefore difficult to know for certain whether two adjacent monitoring intervals represent continuous operation or two operating cycles.
} 


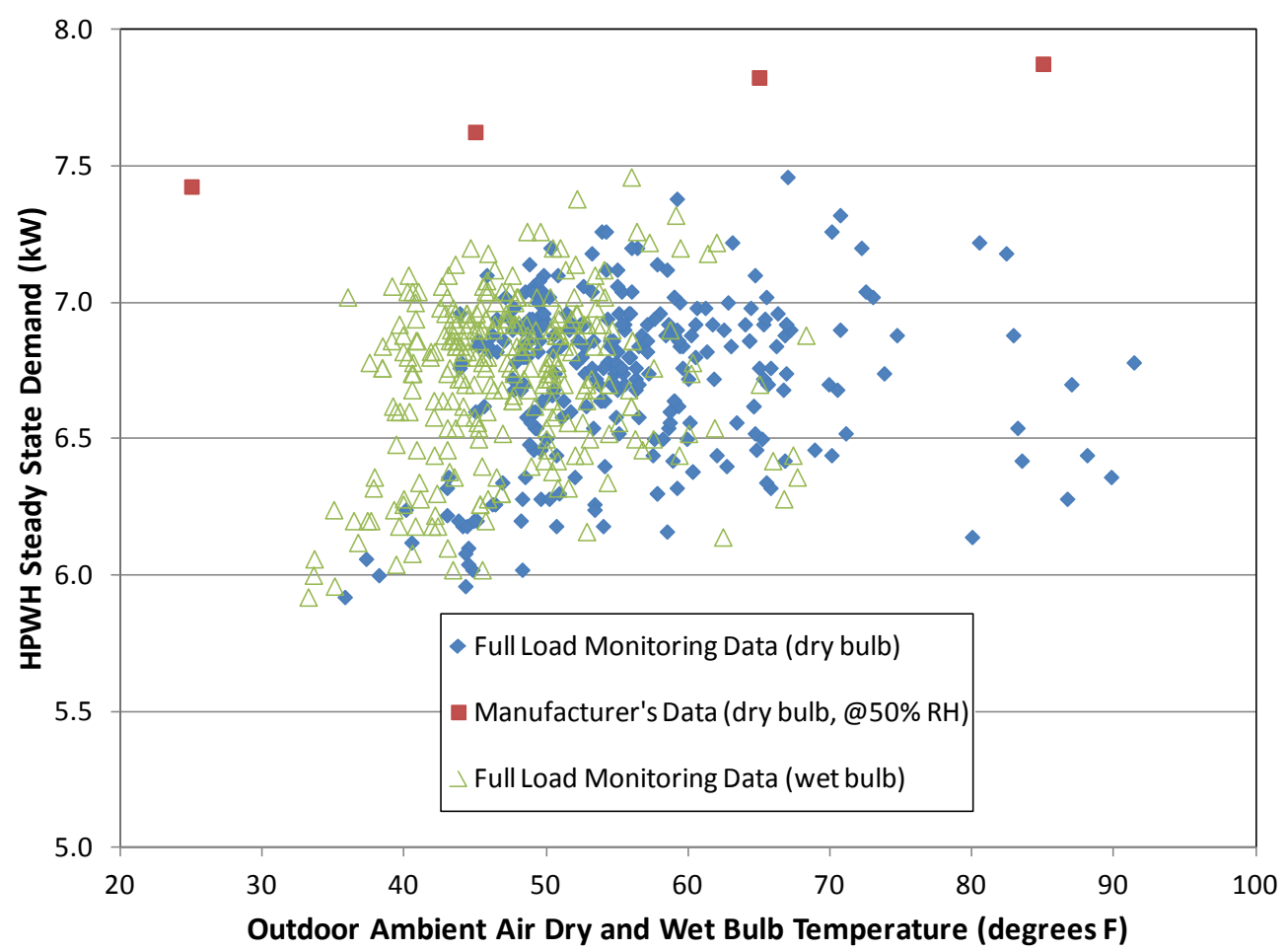

Figure 8. Full-load HPWH demand as a function of outdoor dry-bulb and wet-bulb temperature

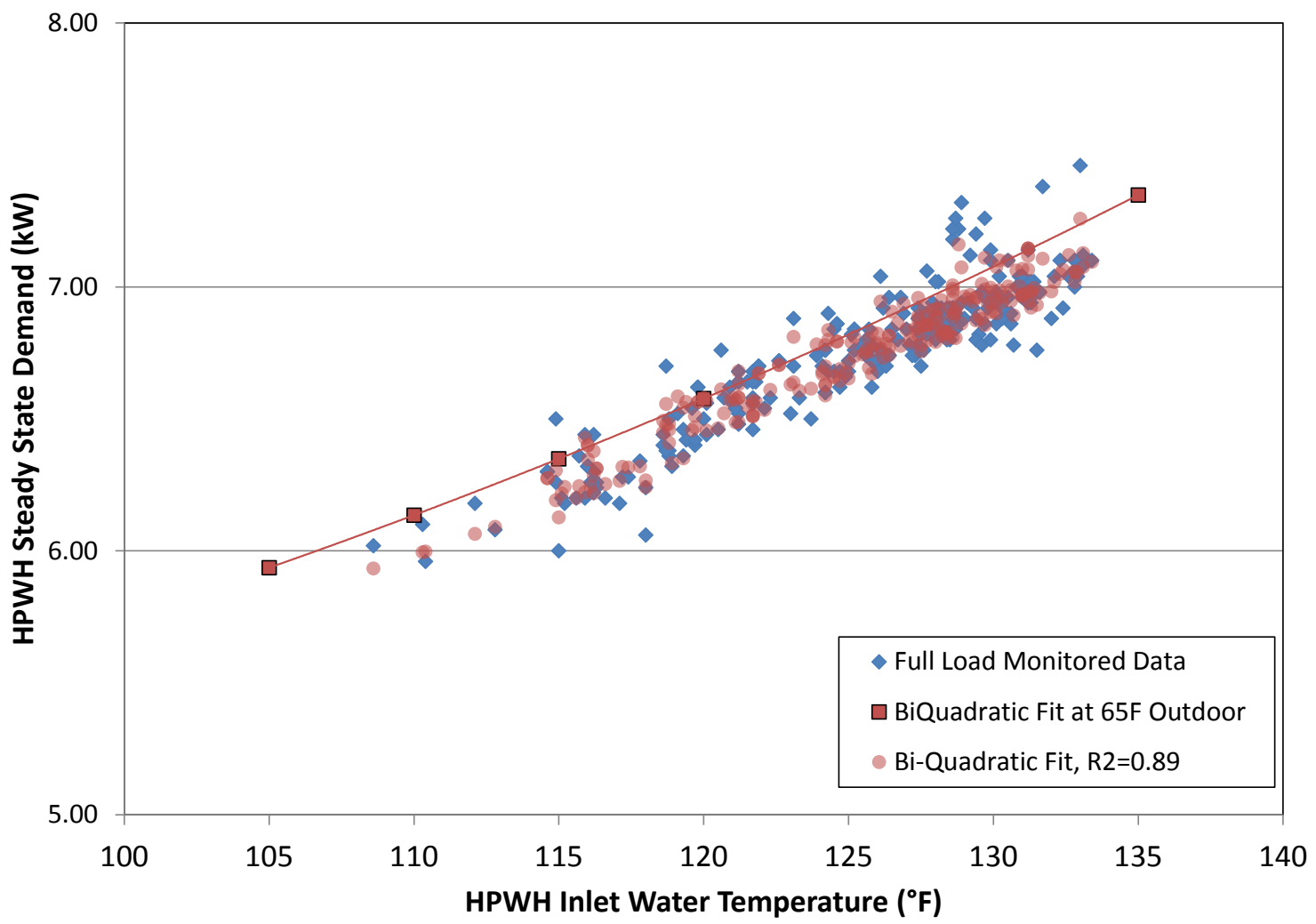

Figure 9. Full-load HPWH demand as a function of inlet water temperature 


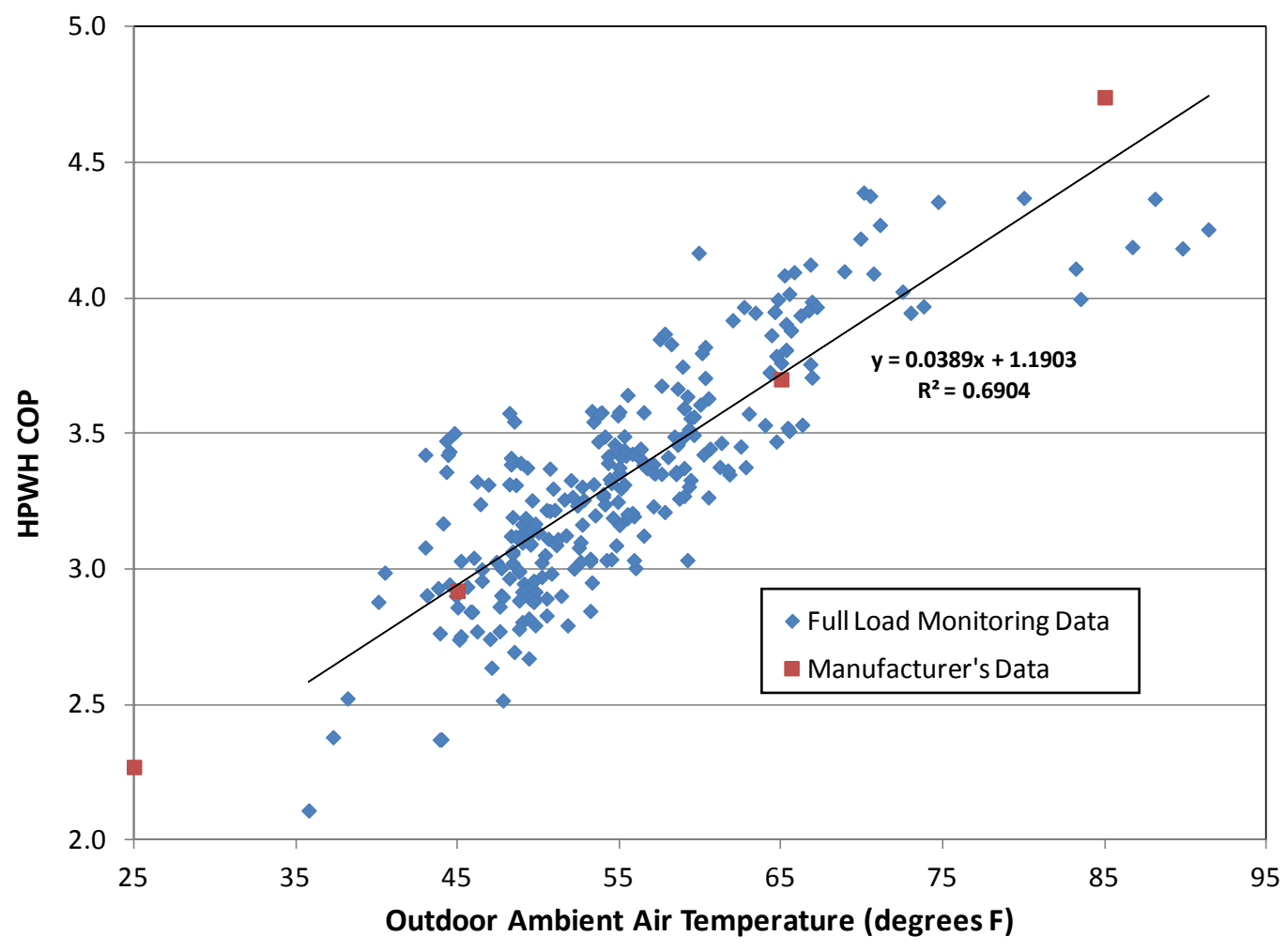

Figure 10. Full-load HPWH COP as a function of outdoor dry-bulb temperature

\subsection{Developing a Heat Pump Water Heater Performance Map}

A multiple linear regression analysis was completed to develop a biquadratic relationship between heat pump power and capacity to outdoor dry-bulb temperature and leaving water temperature. The performance relationship was developed relative to entering water temperature and outdoor air dry-bulb temperature, as shown in Eq. 3 and Eq. 4 below:

$$
\begin{aligned}
& P w r_{H}=a+b(E W T)+c\left(E W T^{2}\right)+\mathrm{d}(\mathrm{OAD})+\mathrm{e}\left(\mathrm{OAD}^{2}\right)+\mathrm{f}(\mathrm{EWT} * \mathrm{OAD}) \text { (Eq. 3) } \\
& \text { Cap }_{H}=a+b(E W T)+c\left(E W T^{2}\right)+\mathrm{d}(\mathrm{OAD})+\mathrm{e}\left(\mathrm{OAD}^{2}\right)+\mathrm{f}(\mathrm{EWT} * \mathrm{OAD})(\text { Eq. } 4)
\end{aligned}
$$

Where:

- $\mathrm{Pwr}_{\mathrm{H}}=\mathrm{HPWH}$ power $(\mathrm{kW})$

- $\mathrm{Cap}_{\mathrm{H}}=$ HPWH heating capacity $(\mathrm{Btu} / \mathrm{h})$

- $\quad \mathrm{EWT}=\mathrm{HPWH}$ entering water temperature $\left({ }^{\circ} \mathrm{F}\right)$

- $\mathrm{OAD}=$ Outdoor air dry-bulb temperature $\left({ }^{\circ} \mathrm{F}\right)$

The Excel linest function was used to derive the regression coefficients based on only full-load monitored data. The sample size fitting this criterion was 393 data points, or a total of 98 hours. As shown in Figure 7 and Figure 9, the biquadratic regression coefficients shown in Table 5 best approximated system performance at ful -load. The degree-of-freedom adjusted R-square 
statistics $^{8}$ for power and capacity were 0.89 and 0.86 , respectively, where values closer to 1 indicate a high goodness of fit. The regression relationships were used to create an input performance map for model interpolation. The map was generated for only the observable range of data; therefore, the model requires extrapolation beyond the range of observed outdoor drybulb and entering water temperatures.

Table 5. Coefficients for the Biquadratic Functions Relating Capacity to Power

\begin{tabular}{ccc}
\hline Coefficient & Capacity & Power \\
\hline a & 21,738 & 5.64 \\
b & $(326.47)$ & $(0.0323)$ \\
c & 1.36766 & 0.00029 \\
d & $2,196.33$ & $(0.0069)$ \\
e & $(4.5235)$ & $(0.00002)$ \\
f & $(4.6923)$ & 0.00015 \\
\hline
\end{tabular}

\subsection{Heat Pump Water Heater Performance Characteristics}

Figure 11 plots daily total hot water usage and heat pump energy delivered on the primary Y-axis and daily HPWH and electric resistance $\mathrm{kWh}$ on the secondary Y-axis. Hot water loads peak during the January/February time frame and are lowest during midsummer (when apartments are not fully occupied and loads are naturally lower) and during breaks in the academic year (Thanksgiving, winter holidays, and spring break). The range in daily loads is high, with day-today variations of 2:1 and seasonal variations of 7:1 to 10:1 not uncommon. Average HPWH energy usage until December 2012 averaged approximately $37 \mathrm{kWh}$ per day, with supplemental electric resistance use during that period totaling only approximately $1 \%$ of total annual consumption. In early December 2012, the HPWH went down again, and electrical consumption spiked to more than $100 \mathrm{kWh} / \mathrm{d}$. After the HPWH was brought back online in late January 2013, the supplemental electric usage (bottom right of graph) dropped back to levels consistent with January 2012. The fact that supplemental electric use was minimal during "normal" system operation suggests that the sizing of the storage tanks and selected set points are appropriate for minimizing resistance heat given the observed loads for this building. ${ }^{9}$

Figure 12 plots daily monitored thermal energy delivered as a function of the total energy consumed by the water-heating system. Thermal energy delivered is defined as the sum of the HPWH and any supplemental resistance electric water heating. The majority of the data (blue symbols) represent times when the HPWH was operational, ${ }^{10}$ and the red symbols indicate days when the water-heating loads were met by electric resistance operation. The wide range of thermal energy delivered to storage, which varies from approximately $60-450 \mathrm{kBtu} / \mathrm{d}$, reflects both the expected seasonal variations in occupancy due to academic housing, day-to-day usage variations, and seasonal climatic influences on hot water demand. For "typical" usage levels of

\footnotetext{
${ }^{8} \mathrm{R}^{2}=1-\mathrm{SSE}(\mathrm{n}-1) / \mathrm{SST}(\mathrm{v})$, where SSE is the sum of the squares of error between the observed and predicted values, SST is the sum of the squares of error between the observed value and the predicted mean, $\mathrm{n}$ is the number of observed full-load data, and $\mathrm{v}$ is the difference between the observed data and regression coefficients.

${ }^{9}$ Note that the monitored HPWH was on a building with five four-bedroom apartments and six two-bedroom apartments (one additional four-bedroom aparmtnet served as the unoccupied "model home"), for a total of 32 occupants. Other buildings have six three-bedroom and six four-bedroom units, totaling 42 occupants. This $31 \%$ higher occupant density would likely result in significantly higher supplemental heat use.

${ }^{10}$ For the periods when the HPWH was operational, electric resistance amounted to $1.1 \%$ of total water-heating use.
} 
approximately $300 \mathrm{kBtu} / \mathrm{d}$, the all-electric resistance water heating consumed approximately 2.5 times as much energy as the HPWH.

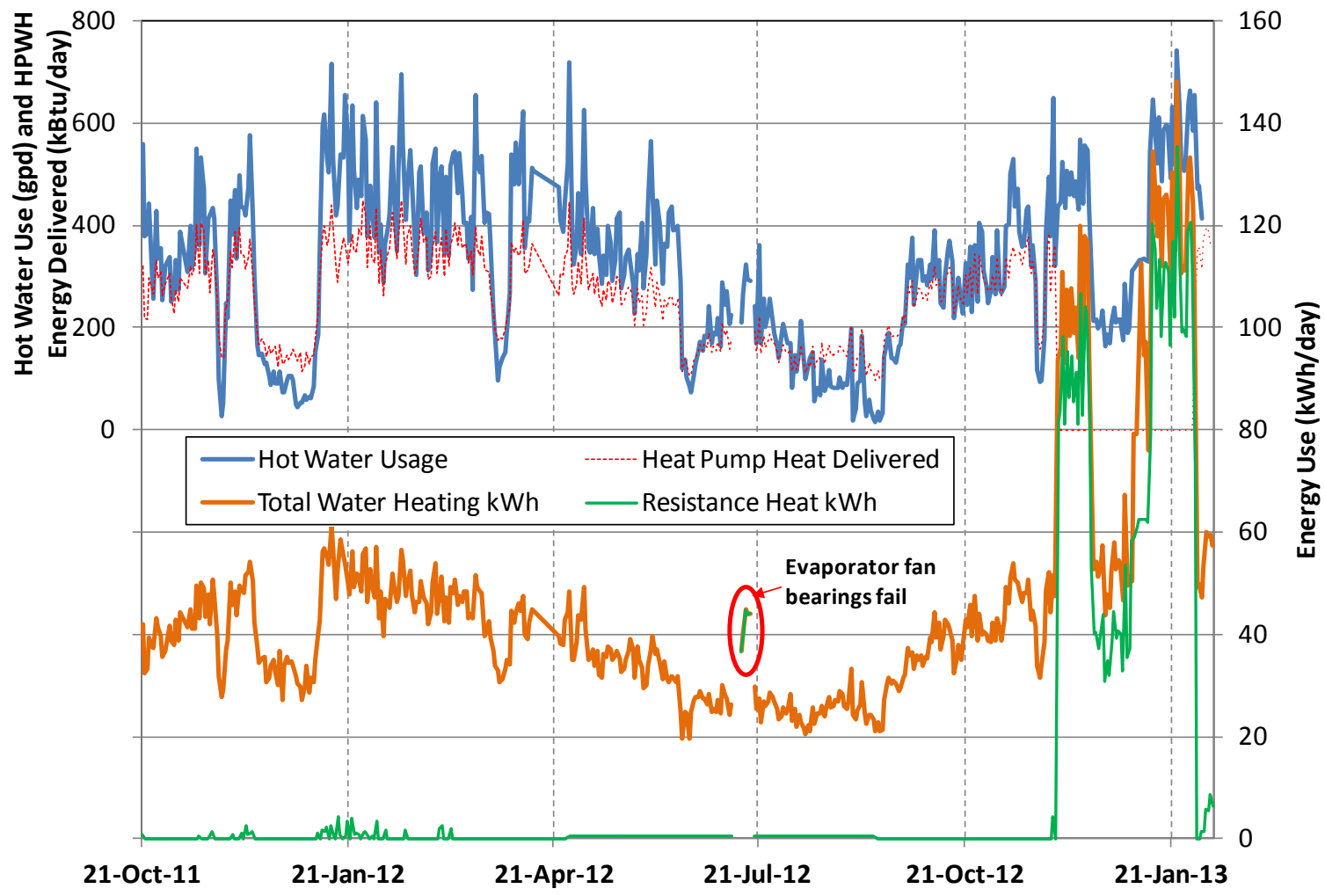

Figure 11. Daily hot water loads, HPWH energy delivered, and energy consumption

Figure 13 compiles the monitored data on a monthly basis. Daily per-capita hot water use and per-apartment electrical use is plotted on the primary $\mathrm{Y}$-axis, and the monthly average system $\mathrm{COP}$ is plotted on the secondary $\mathrm{Y}$-axis. Hot water usage and resulting energy use peaks in the winter months (note that for December 2012 and January 2013, usage is purely electric resistance). For months when the HPWH was operating, COPs ranged from 2.0-2.3, with the unexpected exception of the warmest summer months when COPs fell to the range from 1.7-1.9 range. An average COP of 2.12 was monitored during the period from November 2011 through October 2012. 


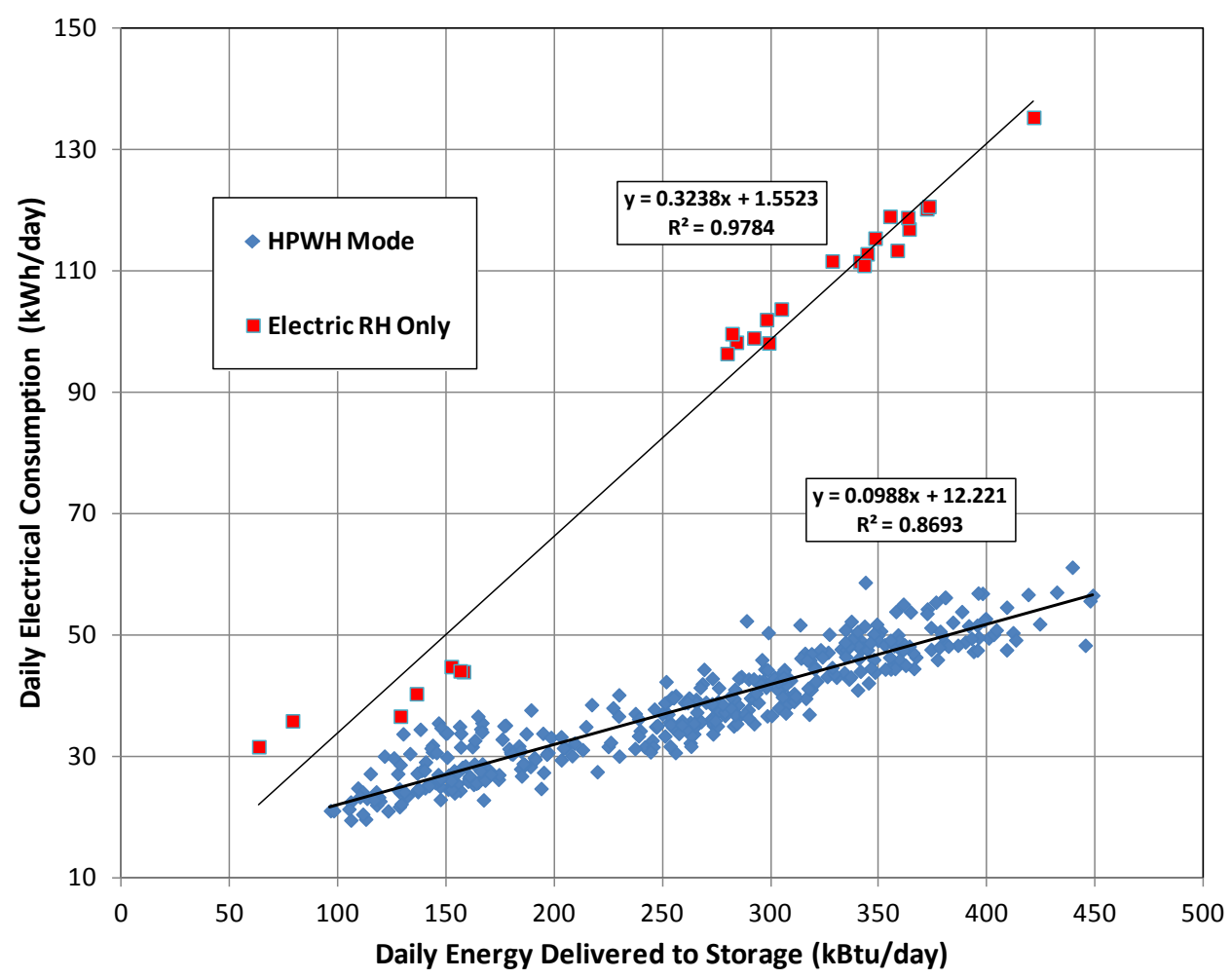

Figure 12. Comparison of daily water-heating energy use to thermal output

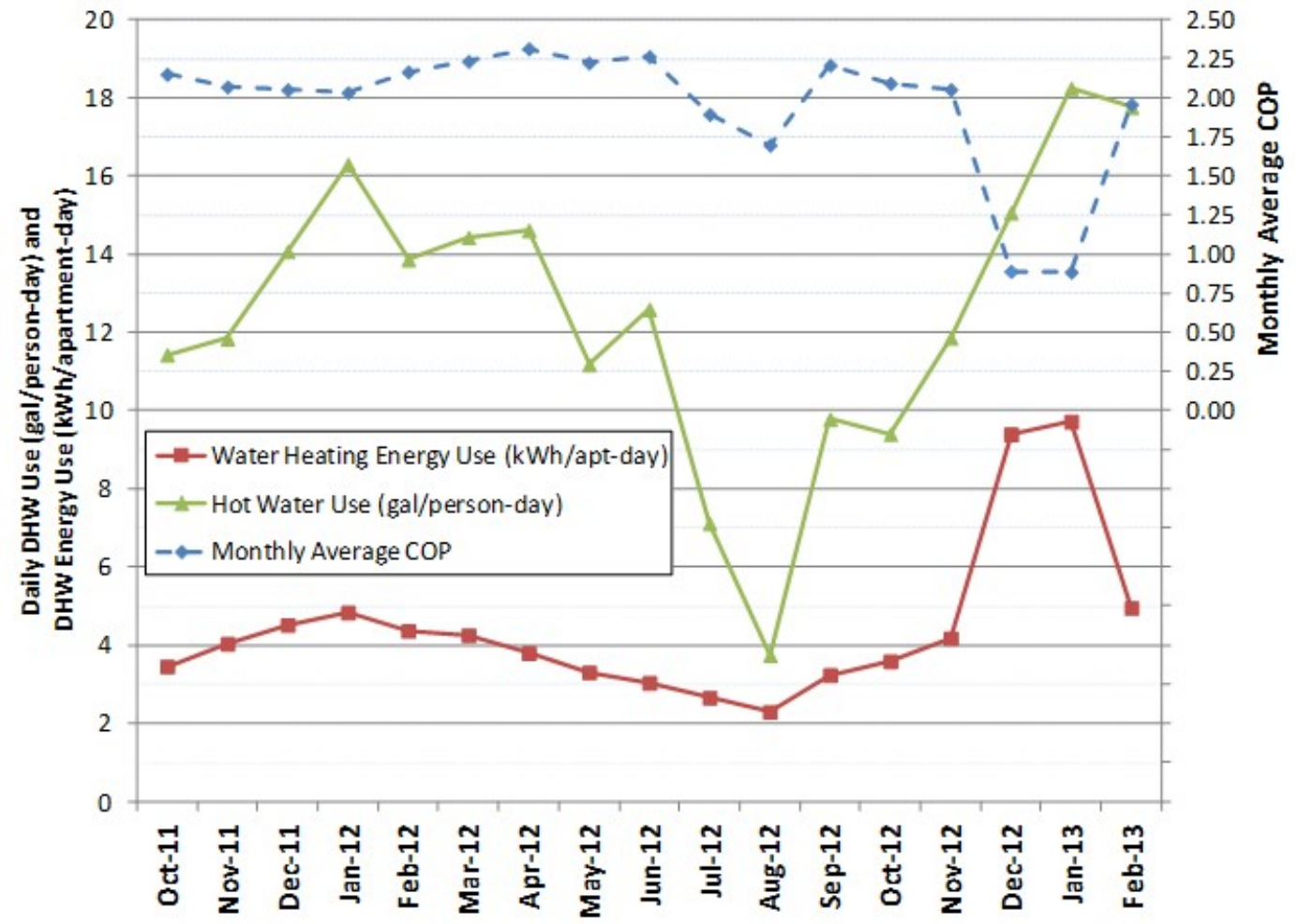

Figure 13. Monthly system performance summary 
The reason for the summer efficiency degradation is counterintuitive because one would expect that efficiencies would be highest during the warmest months. One factor affecting summer performance is high standby energy consumption. With low summer water-heating loads, standby energy becomes a greater fraction of the energy consumed. The HPWH was found to average approximately $450 \mathrm{~W}$ of standby energy usage due to pipe heaters, crankcase heaters, and controls. ${ }^{11}$ In addition, every heat pump cycle begins with a 2 -minute fan and pump operating cycle before the compressor is energized. This draws slightly more than $1 \mathrm{~kW}$ and also represents a thermal loss as heated water from the storage tank is circulated to the outdoor HPWH. Short summer operating cycles would experience this additional performance degradation to a greater extent than winter cycles, when the loads are higher, heating capacity is lower, and the resulting cycle times are longer. This effect is highlighted in Figure 14, which plots the patterns of HPWH operation during the course of three full weeks: a midwinter week, an early fall week, and a midsummer week (when occupancy and loads are low). The Y-axis presents the HPWH run fraction during the 15-minute period, and the X-axis represents all the data sorted from no operation to highest run fraction. In the winter week, only approximately $10 \%$ of the 15 -minute operating intervals had no heat pump operation, whereas the summer week showed that approximately $55 \%$ of the intervals had no heat pump operation. Looking at only the intervals when the heat pump operated for some fraction of the 15-minute period, the mean run time ranged from $30 \%$ during the winter, to $24 \%$ during the fall, and $17 \%$ in the summer. The two key performance factors to highlight in Figure 14 are the seasonality of the HPWH run time during the course of the year and the implication of short-cycling on overall system performance. The effect of short-cycling on system performance has been noted in other work (Gray 2010).

At the end of the field-monitoring work, short-term 1-minute interval logging was implemented to better observe the start-up characteristics of the unit. Results show that that it would typically take from 8-10 minutes for the HPWH to achieve a steady-state capacity situation (defined as when the supply-to-return water temperature differential remains relatively constant). Given that there were only approximately 400 monitoring points defined as full-load operation, this suggests that improved performance could be realized by lengthening the average duty cycle. Several strategies to achieve this include providing additional storage volume in the HPWH tank, increasing the storage tank temperature differential that controls the system's operation, or utilizing a multistage or variable-speed compressor. To evaluate the potential of reducing shortcycling, several additional TRNSYS runs were completed to look at additional storage volume and a larger storage tank temperature dead band, which allows the HPWH to run longer cycles. Increasing the storage volume (and the associated tank losses) of the two tanks from 120 gal to 150 gal was found to reduce annual Sacramento electrical consumption by $1.2 \%$. Increasing the storage tank dead band from $5^{\circ} \mathrm{F}$ to $10^{\circ} \mathrm{F}$ further reduced total water-heating energy use by $0.7 \%$ despite the increased amount of resistance heat with the wider dead band. Further lab and field studies in this area are warranted to better assess performance impacts.

\footnotetext{
${ }^{11}$ Ranging from approximately $250 \mathrm{~W}$ at an ambient temperature of $100^{\circ} \mathrm{F}$ to nearly $600 \mathrm{~W}$ at $40^{\circ} \mathrm{F}$.
} 


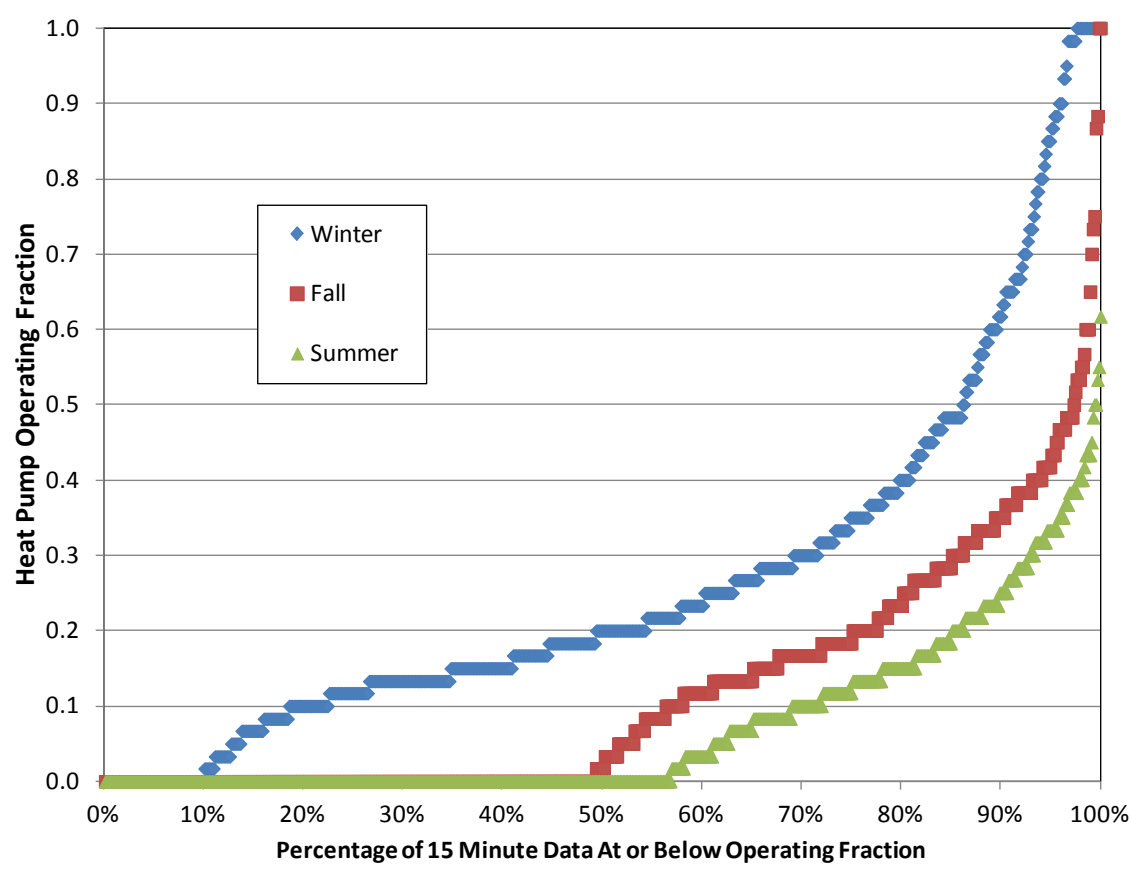

Figure 14. Seasonal characterization of heat pump operation during typical weeks

The reduction in summer loads is due not only to lower student occupancy but also to the impact of cold water inlet temperature seasonal variations, which affect both the energy needed to heat the incoming water up to set point as well as the required ratio of hot to cold mixing for uses such as showers. Figure 15 plots daily average cold water temperature during the course of the monitoring. Data are filtered for 15-minute periods with more than 10 gal of recorded hot water usage to provide greater confidence that the surface-mounted cold water thermocouple is providing a representative reading of the pipe surface temperature. ${ }^{12}$ Hot water load seasonality due to seasonal fluctuations in water heater inlet temperature that are higher than assumed impacts both hot water use and system efficiency.

\footnotetext{
${ }^{12}$ During time periods when the university is not open for instruction (i.e., winter and spring breaks), the average daily cold water temperature becomes more erratic.
} 


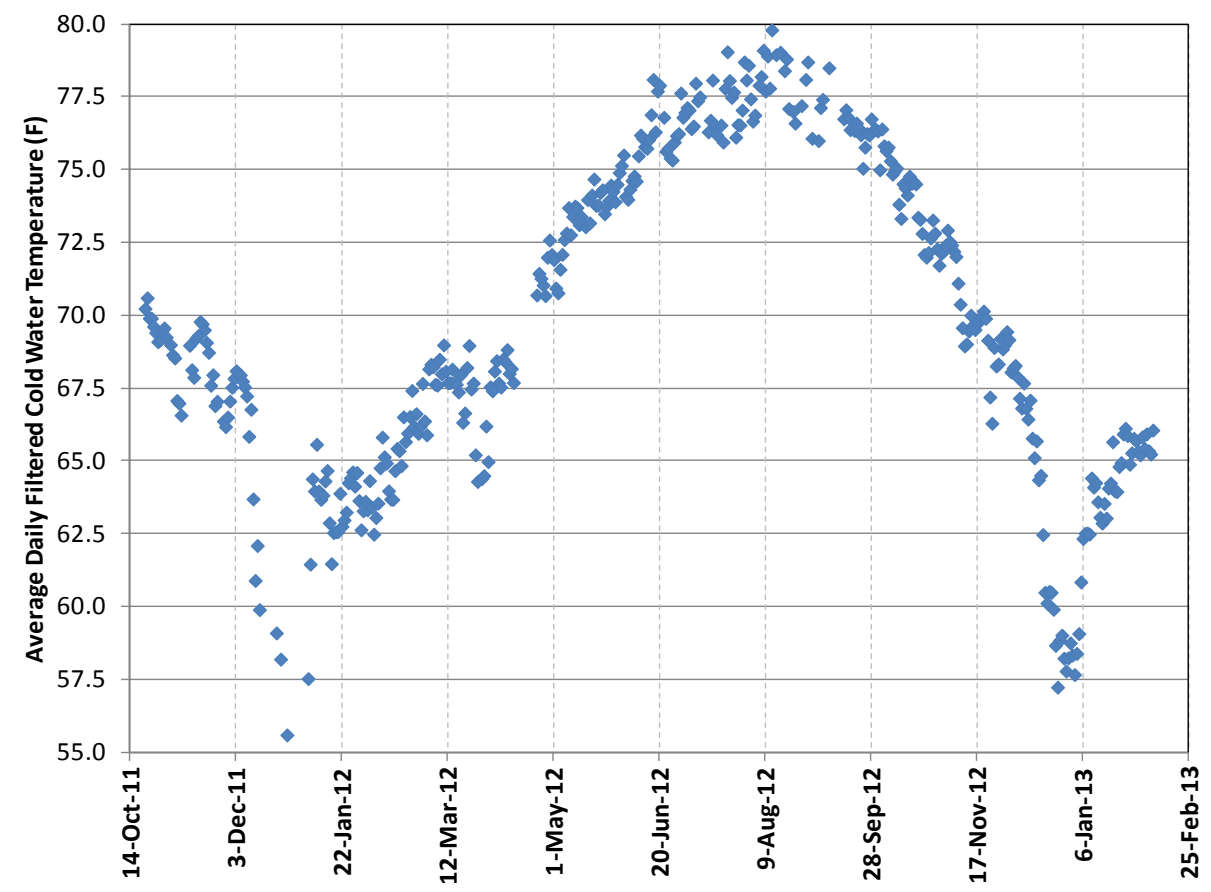

Figure 15. Average daily filtered cold water inlet temperature

\subsection{TRNSYS Model Validation Efforts}

The performance map was developed using the 15-minute full-load monitored data from November 2011 through November 2012. The available full-load data resulted in a performance map that was valid for entering water temperatures ranging from $110^{\circ} \mathrm{F}-135^{\circ} \mathrm{F}$ and outdoor air temperatures ranging from $35^{\circ} \mathrm{F}-95^{\circ} \mathrm{F}$. Although the monitored data were logged at a 15 -minute resolution, it was necessary to run the model at a 15 -second time step to capture the transient effects inherit with the controls.

The model acts by performing a table lookup to determine heating capacity and power, and therefore it is able to simulate only steady-state performance. (Due to the relative size of the storage tanks and the observed hot water loads, the heat pump only operated at full steady-state conditions during 15 minutes for less than $1 \%$ of all the collected monitored data.) To approximate system start-up performance, when the capacity and electrical demand are low as the system builds to full operating conditions, a second start-up heat pump model was developed with a lower rated capacity (50\% of nominal). Program logic controls were added to run this heat pump for the first 3 minutes of any operating cycling, at which point the model transitions to the steady-state performance model. Although this approach is not ideal, the limitations of the TRNSYS steady-state model required some adjustments to better mimic observed performance.

A similar technique was applied when the HPWH sensed outdoor temperatures lower than $40^{\circ} \mathrm{F}$ and lowered the heating set point to $125^{\circ} \mathrm{F}$. A diagram of the entire system, including the three representative heat pumps, is shown in Figure 16. The evaporator fan was a two-speed fan programmed to drop into low speed when outdoor temperatures are higher than $85^{\circ} \mathrm{F}$ to avoid an overcapacity situation. The TRNSYS model also makes the evaporator fan speed and airflow 
fixed parameters read only at model initialization. Using the built-in calculator function, the effect was modeled and added to the simulated heat pump power.

Despite the many embedded thermostat options in TRNSYS, the program lacked a thermostat that had both dead-band parameters and a minimum compressor run time. Using the built-in calculator function, a controller was developed that modeled the control logic of the heat pump so that the on temperature was $135^{\circ} \mathrm{F}$, the off temperature was $140^{\circ} \mathrm{F}$, and there was a minimum compressor run time of 4 minutes. Figure 16 shows that a time-delay model (Type 93) was used to carry state information into the next cycle (first-order hold), and the run-time calculator (Type 980) was used to integrate the control status.

Finally, the unit was set to go to a defrost cycle, wherein heat from the circulated storage tank water was used to remove frost or ice from the evaporator coils at low outdoor conditions. This effect was not observed in the field in the mild Davis, California, climate; therefore, without an available performance map, it was difficult to model. To approximate this effect, any simulation time steps when outdoor temperatures were lower than freezing $\left(32^{\circ} \mathrm{F}\right)$, the compressor was modeled as "off," with supplemental resistance heat used for DHW, as needed. This effect was necessary when modeling HPWH performance in the colder U.S. climates.

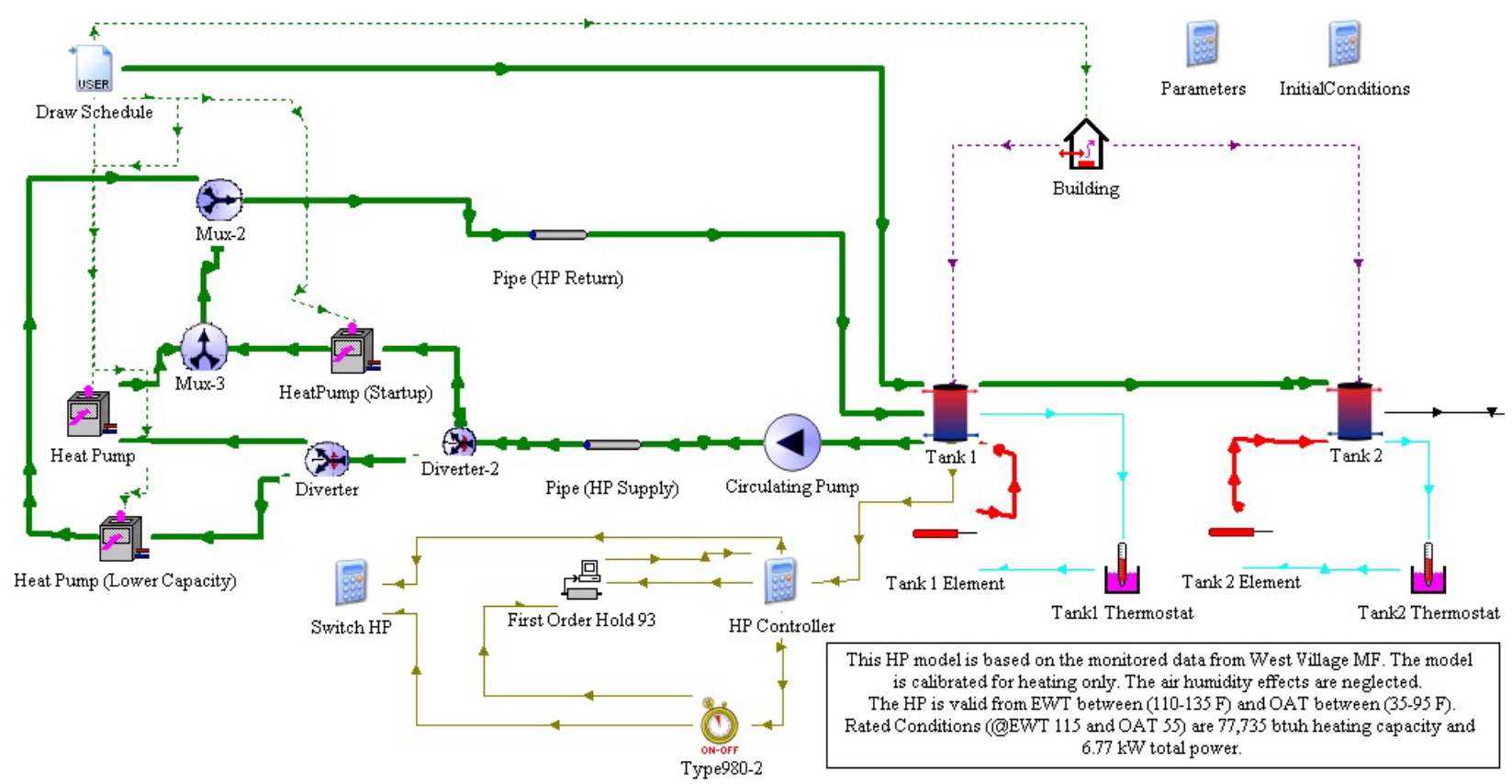

Figure 16. TRNSYS HPWH model configuration

Two sample weeks' worth of monitored data were used to drive the model for the validation exercise: a winter week from February 1, 2013, through February 7, 2013, and a fall week from October 9, 2012, through October 21, 2012. Given that the model responds to "smoothed" hot water loads (i.e., uniform hot water loads during a full 15-minute period), a direct comparison of model to monitored results on a short time step was problematic. Table 6 provides a summary of energy use and thermal energy delivered during each of the two weeks. During the winter, the model was found to slightly overestimate heat pump usage and slightly underestimate electric 
element usage while overpredicting heat pump thermal contribution by approximately $12 \%$. During the fall, the heat pump was able to provide $100 \%$ of the load, and the model provides a good match to the monitored data.

Table 6. Model Validation Results during Typical Winter and Fall 7-Day Period

\begin{tabular}{lcccc}
\hline & $\begin{array}{c}\text { Heat Pump } \\
\text { Energy Use (kWh) }\end{array}$ & $\begin{array}{c}\text { Electric Element } \\
\text { Energy Use } \\
(\mathbf{k W h})\end{array}$ & $\begin{array}{c}\text { Heat Pump } \\
\text { Energy Delivered } \\
\text { (kBtu) }\end{array}$ & $\begin{array}{c}\text { Hot Water } \\
\text { Demand } \\
\text { (kBtu) }\end{array}$ \\
\hline Winter-Monitored Data & 355 & 23 & 2,543 & 2,197 \\
Winter-TRNSYS Model & 365 & 20 & 2,849 & 2,182 \\
Fall-Monitored Data & 284 & - & 2,007 & 1,178 \\
Fall-TRNSYS Model & 282 & - & 1,913 & 1,188 \\
\hline
\end{tabular}

Several adjustments to the model were completed to develop the results shown in Table 6 . The mechanical room housing the storage tanks was modeled as a $540-\mathrm{ft}^{2}$ room, with a thermal capacitance of $2,105 \mathrm{Btu} /{ }^{\circ} \mathrm{F}$ and a heat transfer coefficient to outdoors equal to $23.26 \mathrm{Btu} /(\mathrm{hr}-$ ${ }^{\circ} \mathrm{F}$ ). This assumption provided a reasonable alignment with seasonal mechanical room temperatures. $^{13}$

The HPWH thermostat location was observed to be midway between the supply and return port locations on the first tank, roughly at the tank midpoint. To better align the data, the location for the electric element was moved one node higher (so that some mixing with the tank would occur after the heat pump supply). The electric element location, however, was assumed to be at the bottom node of the tank to allow time for adequate mixing before supply.

\subsection{Projected Performance in Different Climates}

The validated model was run through a series of different climates with climate-adjusted hot water loads. In addition to the HPWH case, conventional all-electric and gas storage cases were simulated with TRNSYS for comparison. For the natural gas option, the two storage water heaters were modeled with an input rating of $309 \mathrm{kBtu} / \mathrm{hr}$ and a thermal efficiency of $80 \%$. The draw profile supplied to the simulation was acquired from ASHRAE Service Water Heating guidelines. To account for typical recirculation losses, the hourly fixture end usage was increased by $30 \%$.

Table 7 shows the annual performance of the heat pump in the climates of Phoenix, Houston, Sacramento, Seattle, Denver, and Chicago. Typically in hot and mild climates, the HPWH is projected to achieve annual COPs higher than 2.0. In the colder climates, such as Denver and Chicago, the HPWH is unable to fully meet the load. In addition, at outdoor temperatures lower than $32^{\circ} \mathrm{F}$, the compressor was locked out, and all heating was provided by electric resistance. The water-heating loads are also up to $30 \%$ higher in these climates relative to the warmer climates, which also accounts for the higher resistance heat and heat pump use. The waterheating energy delivered with the HPWH configuration is slightly higher in warmer climates because the heat pump supplies $140^{\circ} \mathrm{F}$ water to the storage tank, whereas the thermostats in the conventional base case runs were set to $135^{\circ} \mathrm{F}$ to better align with average delivery temperatures. The supplemental electric resistance elements in the heat pump configuration were set to $120^{\circ} \mathrm{F}$;

\footnotetext{
${ }^{13}$ Mechanical room temperatures were not monitored.
} 
therefore, in colder climates, where the unit relies more heavily on resistance heating, the delivered water heater energy is less.

The HPWH simulations were projected save 49\%-59\% electrical energy savings relative to the electric base case. Figure 17 shows the comparison in annual operating costs for each option given the assumed utility rates. HPWH operating costs and overall economics are sensitive to factors such as utility rates, climate, system plumbing configuration, storage tank sizing, hot water load magnitude, and operating set points. Performance sensitivity to these site-specific factors was observed both in this study and reported in prior field-monitoring efforts (Gray 2010).

Table 7. HPWH, Electric, and Gas Water Heater Performance Comparison in Selected Climates

\begin{tabular}{|c|c|c|c|c|c|c|}
\hline & Phoenix & Houston & Sacramento & Seattle & Denver & Chicago \\
\hline \multicolumn{7}{|l|}{$\begin{array}{l}\text { HPWH ( } 140^{\circ} \mathrm{F} \text { heat pump } \\
\text { set point, } 120^{\circ} \mathrm{F} \text { backup) }\end{array}$} \\
\hline $\begin{array}{l}\text { Heat Pump Energy Input } \\
\text { (kWh/yr) }\end{array}$ & 14,692 & 16,385 & 17,850 & 18,838 & 15,628 & 15,185 \\
\hline $\begin{array}{l}\text { Electric Resistance Energy } \\
\text { Use (kWh/yr) }\end{array}$ & - & - & 275 & 1,150 & 8,161 & 10,562 \\
\hline $\begin{array}{l}\text { Water-Heating Energy } \\
\text { Delivered (kBtu/yr) }\end{array}$ & 104,715 & 117,475 & 129,561 & 146,575 & 143,338 & 145,876 \\
\hline Annual System COP & 2.09 & 2.10 & 2.09 & 2.15 & 1.77 & 1.66 \\
\hline \multicolumn{7}{|l|}{$\begin{array}{l}\text { Electric Resistance } \\
\text { Storage ( } 135^{\circ} \mathrm{F} \text { set point) }\end{array}$} \\
\hline $\begin{array}{l}\text { Electric Resistance Energy } \\
\text { Use (kWh/yr) }\end{array}$ & 32,020 & 36,043 & 41,636 & 49,208 & 49,616 & 50,777 \\
\hline $\begin{array}{l}\text { Water-Heating Energy } \\
\text { Delivered (kBtu/yr) }\end{array}$ & 97,336 & 110,181 & 127,479 & 151,882 & 153,164 & 156,823 \\
\hline Water-Heating Efficiency & $89 \%$ & $90 \%$ & $90 \%$ & $90 \%$ & $90 \%$ & $90 \%$ \\
\hline $\begin{array}{l}\text { HPWH kWh Savings vs. } \\
\text { Elec. }\end{array}$ & $54 \%$ & $55 \%$ & $56 \%$ & $59 \%$ & $52 \%$ & $49 \%$ \\
\hline \multicolumn{7}{|l|}{$\begin{array}{l}\text { Natural Gas } \\
\left(135^{\circ} \mathrm{F} \text { set point }\right)\end{array}$} \\
\hline $\begin{array}{l}\text { Natural Gas Use } \\
\text { (therms/yr) }\end{array}$ & 1,363 & 1,534 & 1,773 & 2,095 & 2,112 & 2,162 \\
\hline $\begin{array}{l}\text { Water-Heating Energy } \\
\text { Delivered (kBtu/yr) }\end{array}$ & 97,213 & 110,044 & 127,333 & 151,721 & 153,009 & 156,666 \\
\hline Water-Heating Efficiency & $71 \%$ & $72 \%$ & $72 \%$ & $72 \%$ & $72 \%$ & $72 \%$ \\
\hline
\end{tabular}

A more generic look at HPWH economics confirms that relative to natural gas water heating, HPWHs face a challenging prospect with the low natural gas rates currently found in much of the country. A simplistic method to provide a first-cut assessment of HPWH viability based on local utility rates is shown in Figure 18. The graph shows the maximum average electric rate that would result in operating cost neutrality at a given local natural gas rate and assumed HPWH operating efficiency. An example case with natural gas at $\$ 1.10 /$ therm and average electric rates of $\$ 0.14 / \mathrm{kWh}$ suggest that annual COP greater than 2.5 is needed for the HPWH to offer any operating cost advantage. Current performance expectations suggest that COPs ranging from 22.5 are readily achievable, with higher efficiencies possible in applications that provide for favorable operating conditions and extended operating cycles. 


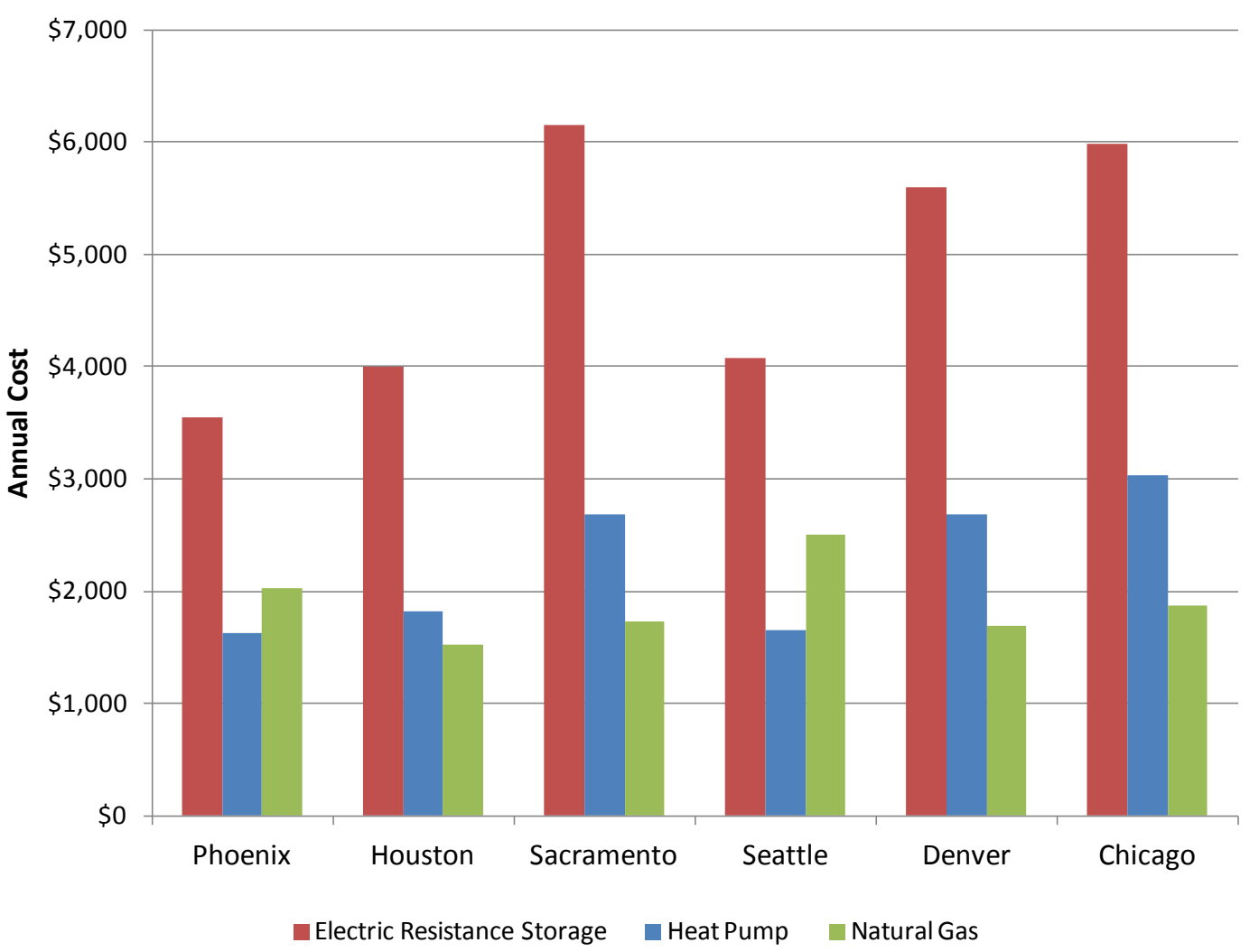

Figure 17. Projected annual operating cost comparison in selected climates

Overall HPWH cost-effectiveness depends on both operating cost savings and incremental cost. The installed cost for the A.O. Smith HPWH was \$22,300. Relative to an electric resistance base case system, the incremental HPWH cost is approximately $\$ 20,000$. The central gas base case is more difficult to estimate because the cost of bringing natural gas to the site (especially if the application is all electric, as implemented at West Village) can be significant. For this application, we assume a $\$ 10,000$ incremental HPWH cost relative to central gas water heating. With TRNSYS projected annual savings of $\$ 1,920-\$ 3,475$ per year compared to electric water heating, simple paybacks of 5.8-10.4 years are projected. To achieve similar paybacks relative to gas water heating, annual savings of $\$ 960$ to $\$ 1,720$ are needed. Achieving this level of savings in many parts of the country is currently difficult, although in several states (e.g., Georgia, North Carolina, Alabama, Florida, and Hawaii) the relative costs of electricity to natural gas are more favorable (U.S. Energy Information Administration 2016a; U.S. Energy Information Administration 2016b). 


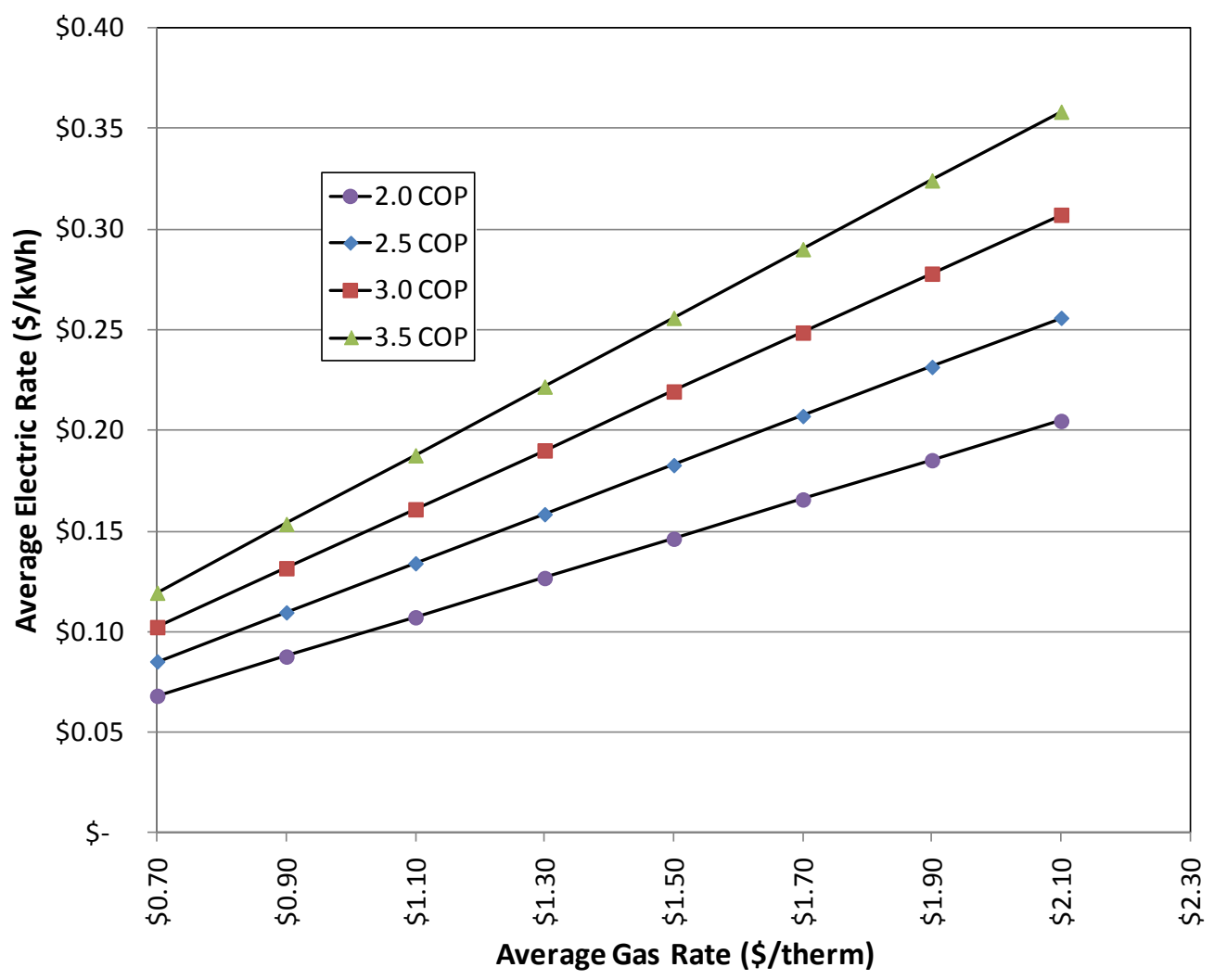

Figure 18. HPWH breakeven costs as a function of COP and utility rates 


\section{Conclusions}

This research effort focused on the monitoring and evaluation of a central HPWH installed in student apartments at the University of Califonia, Davis, campus. The evaluation process included validating a TRNSYS air-to-water heat pump model with the field data and using the model to provide an initial comparison of multifamily HPWH performance in six U.S. climates with varying utility rates.

The primary research questions addressed include:

1. What is the measured performance and reliability of the central HPWH, and how does it compare to expectations from modeling and manufacturer claims?

Manufacturer's performance values for the A.O. Smith E-Tech WH115-HTC are based on steady-state operation at a flow rate of $25 \mathrm{gpm}$ and an inlet water temperature of $100^{\circ} \mathrm{F}$. Field monitoring indicated an actual flow rate of $20 \mathrm{gpm}$ with inlet water temperatures significantly higher than $100^{\circ} \mathrm{F}$ due to the plumbing configuration, which resulted in recirculation return water being mixed with the cold water supply. In addition, the sizing of the storage and the programmed temperature dead band resulted in limited steady-state operation. Although overall steady-state COPs in the range from 3.0-4.0 were in line with manufacturer's data, high standby parasitics and frequent short-cycling degraded the annual COP to 2.12. A multistage HPWH would likely demonstrate improved efficiencies by extending the average compressor run-cycle length. Another strategy to extend cycle times would be a more sophisticated control algorithm to allow for a larger dead band or overcharging of storage by $5^{\circ} \mathrm{F}-10^{\circ} \mathrm{F}$, if the system has not run for a minimum amount of time. Preliminary modeling efforts suggest that this might amount to a $2 \%$ reduction in annual electrical consumption, but more evaluation is needed to better document performance.

The installed HPWH was found to operate reliably during the 16-month period. Start-up problems in Phase I due to improper installation and commissioning were not observed in Phase II because the installers gained experience with the technology. The one reliability concern experienced with the monitored unit was the need to replace the evaporator fan motor in July 2012 due to bearing failures. This apparently happened at one of the other 15 units installed in Phase I. Longer-term reliability of the units and associated maintenance costs need to be studied to better understand life-cycle economics.

2. How viable is the central HPWH system to other conventional options under varying retail rate scenarios?

HPWHs will provide significant electric savings relative to electric resistance water heaters, with TRNSYS projected savings ranging from $49 \%-59 \%$ based on climate impacts. TRNSYS projected annual savings of $\$ 1,920-\$ 3,475$ per year compared to electric water heating results in simple paybacks in the range from 6-10 years for the cases evaluated. If natural gas is available, the economics are generally not favorable as long as natural gas rates are low ( $\$ 1 /$ therm). Some southeastern states and Hawaii may have favorable HPWH economics due to high gas rates relative to electricity. Opportunities for improved performance should exist by optimizing system performance to limit compressor short-cycling and avoiding high HPWH inlet water 
temperatures (improving efficiencies). Current HPWH equipment costs are high and would benefit from increased market demand and competition in the marketplace.

3. Under what load and ambient conditions does the HPWH fail to meet the load, and how frequently does this occur?

Under the conditions observed at the University of California, Davis, West Village project, the monitored HPWH used very little supplemental heating (1.1\% of annual water-heating electrical use) when the HPWH was operating properly. This suggests that the sizing of the unit and the supplemental storage is appropriate for the building application (six two-bedroom and six fourbedroom units). Because the monitored configuration served only 32 occupants, ${ }^{14}$ more heavily loaded units would tend to experience more supplemental electric use. The need for supplemental heat was limited to midwinter conditions with low ambient air temperatures $\left(<45^{\circ} \mathrm{F}\right)$ and an average hot water demand of $3 \mathrm{gpm}$ during periods of 30 minutes or longer.

4. How does the ratio of the HPWH sizing to peak load compare to typical single-family applications, and what are the performance implications?

The 10.5-t nominal HPWH with 240 gal of storage was sized to meet the hot water loads of building with 42 occupants. The $2,500 \mathrm{Btu} / \mathrm{h}$ compressor capacity per person is consistent with a typical single-family residential HPWH $(6,000-8,000 \mathrm{Btu} / \mathrm{h}$ for a typical family size of three), but the 6 gal of storage per person is considerably less than the 15-20 gal common to the singlefamily HPWH. The greater diversity in hot water loads observed with the multifamily application resulted in much less resistance heat consumption than has typically been reported in prior single-family HPWH research (Amarnath et al 2012); however, short-cycling of the compressor resulted in much lower seasonal efficiencies than observed in the full-load data. Optimizing storage sizing and control set points and potentially introducing the multistage compressor should allow the central HPWH to operate at improved efficiencies.

\footnotetext{
${ }^{14}$ One of the four-bedroom units was the unoccupied model used for leasing purposes.
} 


\section{References}

Amarnath, A., and J. Bush. 2012. "HWSIM: Development and Validation of a Residential Hot Water Distribution System Model." Proceedings of the 2008 ACEEE Summer Study on Energy Efficiency in Buildings.

ASHRAE. 2011. "Chapter 50: Service Water Heating.” In 2011 ASHRAE Handbook: HVAC Applications. Atlanta, GA.

Backman, C., and M. Hoeschele. 2013. Validation of a Hot Water Distribution Model Using Laboratory and Field Data. Davis, CA: Alliance for Residential Building Innovation.

D\&R International, Ltd. 2010. EnergyStar ${ }^{\circledR}$ Water Heater Market Profile (Technical Report BOA\#4200000327). Washington, D.C.: U.S. Department of Energy.

Dakin, B., C. Backman, M. Hoeschele, and A. German. 2012. West Village Community: Quality Management Processes and Preliminary Heat Pump Water Heater Performance. Davis, CA: Alliance for Residential Building Innovation.

Gray, C. 2010. "Energy Efficiency Potential of Heat Pump Water Heaters in Commercial Buildings." Proceedings of the 2010 ACEEE Summer Study on Energy Efficiency in Buildings.

Kerlin, K. 2013. “A Year Later: Progress at UC Davis West Village.” UC Davis News, February 1. https://www.ucdavis.edu/news/year-later-progress-uc-davis-west-village.

Pacific Gas and Electric Company. 2010. Laboratory Evaluation and Field Testing of Residential Heat Pump Water Heaters (Technical Report \#:491-10.04).

TESS. 2011. T.E.S.S. Component Libraries for TRNSYS v. 17.01 (released January 1, 2011). Madison,WI: Thermal Energy System Specialists, LLC.

U.S. Energy Information Administration. 2014. "2014 Average Monthly Bill— Residential.” http://www.eia.gov/electricity/sales_revenue price/pdf/table5 a.pdf.

U.S. Energy Information Administration. 2016a. "Electric Power Monthy." http://www.eia.gov/electricity/monthly/epm table_grapher.cfm?t=epmt 5 _ 6 b.

U.S. Energy Information Administration. 2016b. "Natural Gas

Summary." http://www.eia.gov/dnav/ng/NG_SUM_LSUM A EPG0_PRS_DMCF_M.htm.

Zhang, Y., C. Bonneville, S. Wilson, M. Maroney, J. Staller, and J. Yun Wei. 2012. "Using Energy Flow Analysis to Assess Energy Savings from Recirculation Controls in Multi-Family Central Domestic HotWater Systems." ASHRAE Transactions (118)2. 


\section{Appendix}

The following graphs provide additional detailed results from the TRNSYS modeling validation.

In addition to modeling the heat pump performance accurately, it was critical to capture the temperature dependency of the unit's standby power. For a full week of operation, Figure 19 plots monitored outdoor dry-bulb temperature (secondary Y-axis) and monitored HPWH power (blue line). The graph plots only HPWH demand up to $1.0 \mathrm{~kW}$ because it focuses on the standby data around $0.5 \mathrm{~kW}$. The red symbols plot 15 -minute demand from the TRNSYS validation simulation. The modeled standby varies from slightly $500 \mathrm{~W}$ during nighttime periods when outdoor temperatures are in the low $50 \mathrm{~s}$ to $300-350 \mathrm{~W}$ as temperatures rise higher than $80^{\circ} \mathrm{F}$.

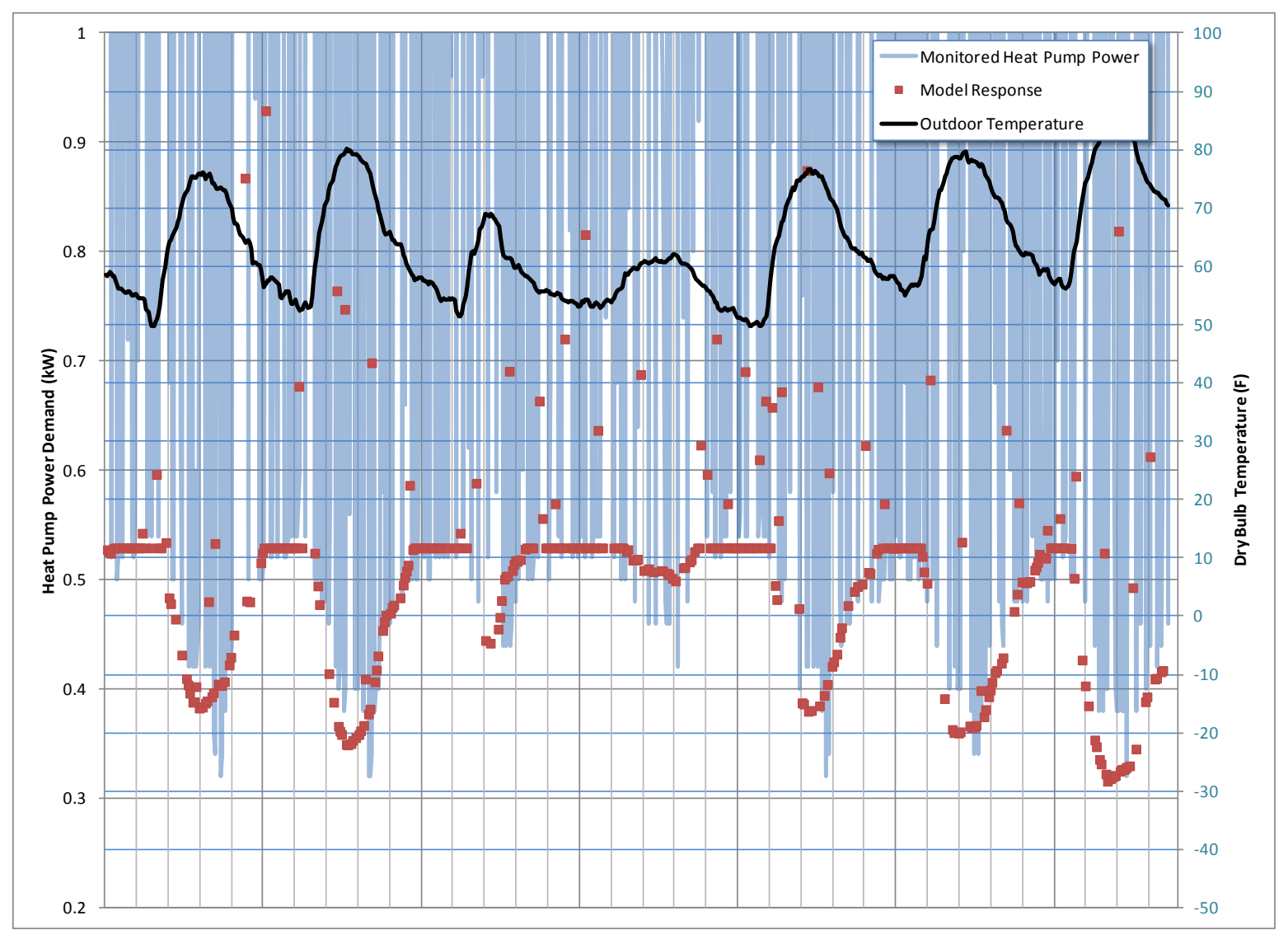

Figure 19. Standby power dependence with air temperature

The heat pump supply and return temperatures reported by the model aligned well with the monitored data, as shown in Figure 19 and Figure 20. In the winter (Figure 19), the heat pump controls reduce its output temperature under low outdoor dry-bulb conditions. In the fall, the outdoor dry-bulb temperatures remain above the temperature threshold, and the supply and return temperature remain stable. The return temperature during the fall is, on average, a few degrees warmer than the model prediction. The fall week observed had little full-load operation; and during periods of relaxed operation, the water mixed with the tank, and higher temperatures were reported. In general, there is greater observed variation with the monitored data because the model relies on smoothed hot water loads for the duration of the 15 minutes. 


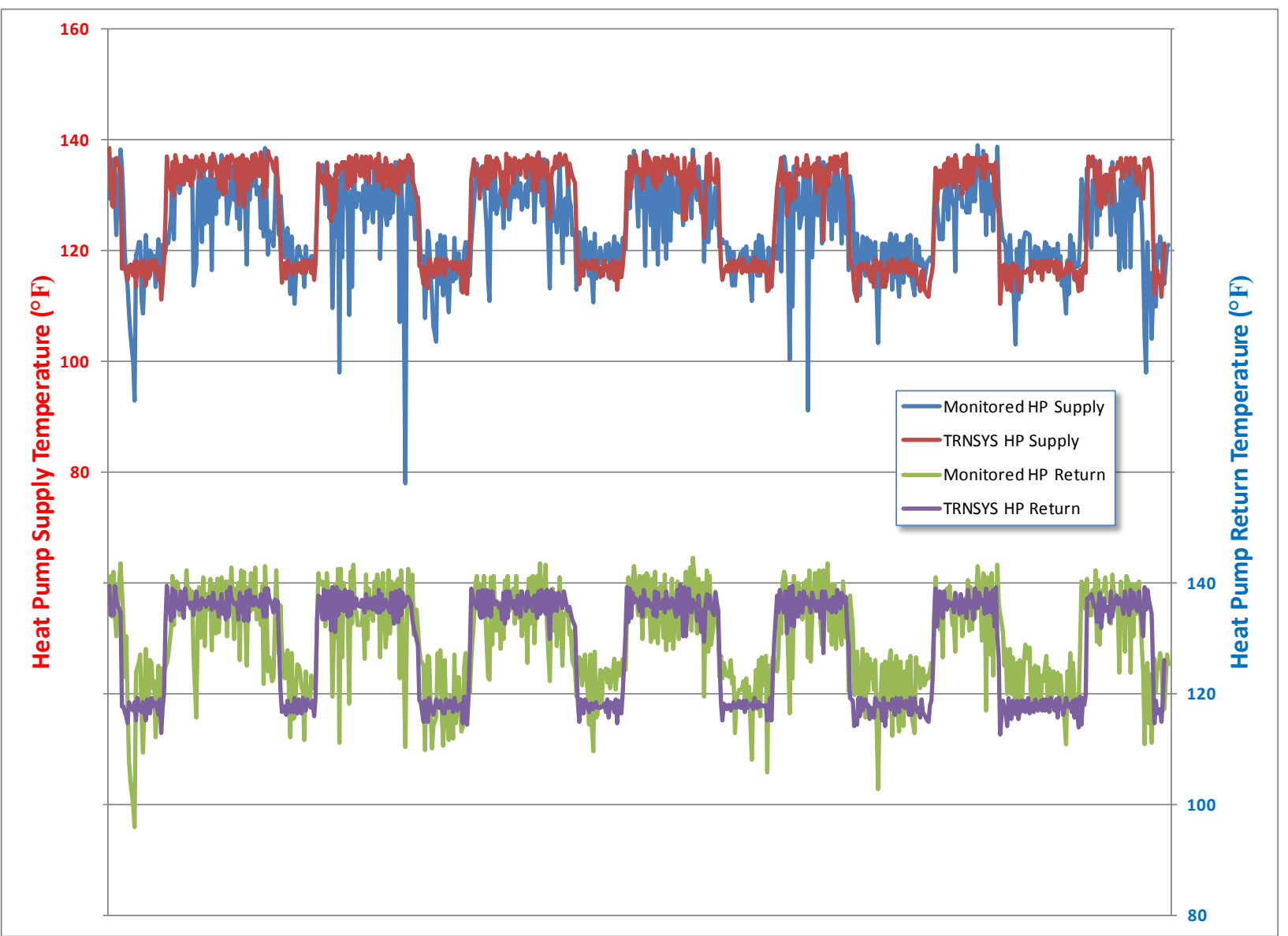

Figure 20. Validation of model performance under typical winter conditions 


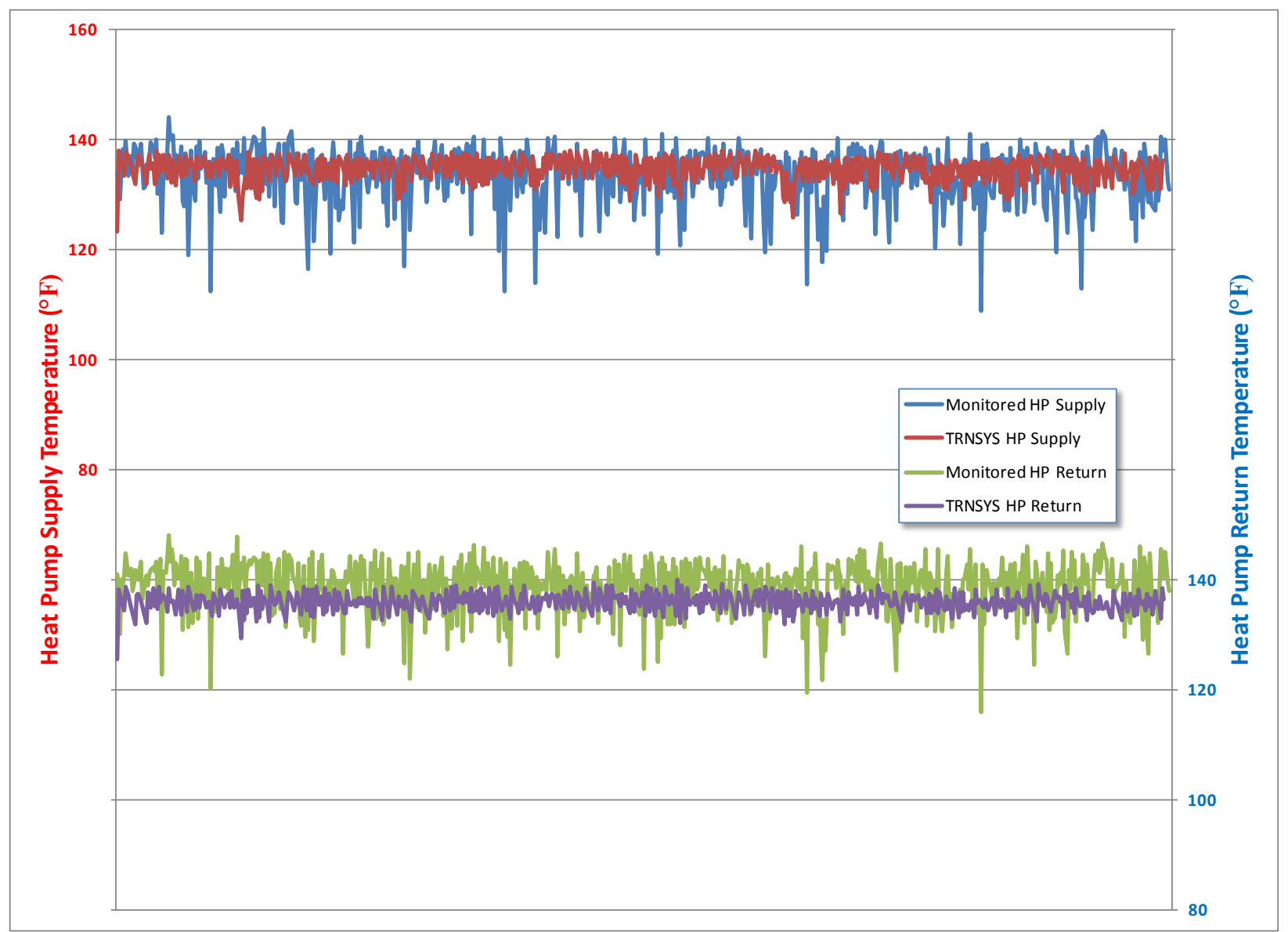

Figure 21. Validation of model performance under typical fall conditions 
